\title{
NBSIR 87-3597
}

\section{XCOM: Photon Cross Sections on A Personal Computer}

M. J. Berger and J. H. Hubbell

U.S. DEPARTMENT OF COMMERCE

National Bureau of Standards

Gaithersburg, MD 20899

July 1987

Prepared for:

U.S. DEPARTMENT OF COMMERCE

National Bureau of Standards

Office of Standard Reference Data

Gaithersburg, MD 20899

Department of Energy

Office of Health and Environmental Research

Washington, DC 20545 



\section{XCOM: PHOTON CROSS SECTIONS ON A PERSONAL COMPUTER}

M. J. Berger and J. H. Hubbell

U.S. DEPARTMENT OF COMMERCE

National Bureau of Standards

Gaithersburg, MD 20899

July 1987

Prepared for:

U.S. DEPARTMENT OF COMMERCE

National Bureau of Standards

Office of Standard Reference Data

Gaithersburg, MD 20899

Department of Energy

Office of Health and Environmental Research

Washington, DC 20545

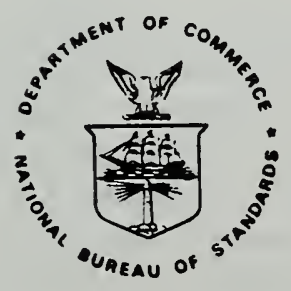

U.S. DEPARTMENT OF COMMERCE, Malcolm Baldrige, Secretary NATIONAL BUREAU OF STANDARDS, Ernest Ambler, Director 

XCOM: Photon Cross Sections on a Personal Computer

\author{
M. J. Berger and J. H. Hubbell \\ Center for Radiation Research \\ National Bureau of Standards \\ Gaithersburg, MD 20899
}

\begin{abstract}
A computer program and data base are presented which can be used to calculate, with a personal computer, photon cross sections for scattering, photoelectric absorption and pair production, as well as total attenuation coefficients, in any element, compound or mixture, at energies from $1 \mathrm{keV}$ to $100 \mathrm{GeV}$.
\end{abstract}

\title{
1. Introduction
}

Data on the scattering and absorption of photons ( $x$-rays, gamma rays, bremstrahlung) are required for many scientific, engineering and medical applications. The number of materials for which photon cross sections are needed is large and ever increasing. Available tables [1-11] usually include cross sections for many (but not all) elements. Some tables $[1,2,6,11]$ also contain data for a limited number of compounds and mixtures. In practice it is not possible to meet all cross-section requirements adequately by means of printed tables. Moreover, the cross sections are often needed at photon energies other than those included in the tables.

Photon cross sections for compounds can of course be obtained rather accurately (except at energies close to absorption edges) as weighted sums of the cross sections for the atomic constituents. However, the required numerical work is tedious, and the task is further complicated by the fact that photoabsorption cross sections and total attenuation coefficients are discontinuous at absorption edges. The presence of these discontinuities makes it desirable that cross section tables for compounds include photon energies immediately above and below all the absorption edges for all the atomic constituents, and this requires much additional interpolation.

A convenient alternative approach is to generate the cross sections and attenuation coefficients for compounds and mixtures as needed, using a personal computer. This paper describes a computer program called XCOM which carries out this task quickly on IBM-compatible personal computers, for any element, compound or mixture, at energies between $1 \mathrm{keV}$ and $100 \mathrm{GeV}$. The program makes use of a database of cross sections for the elements that is stored in compressed form on a single floppy disk.

The XCOM program can generate cross sections on a standard energy grid (spaced approximately logarithmically), or on a grid selected by the user, or for a mix of both grids. Cross sections at energies immediately above and 
below all absorption edges are automatically included. XCOM provides two forms of output: (a) tables which correspond closely in format to existing tables in the literature; (b) user-selected arrays which are convenient for further computer calculations.

The program provides total cross sections and attenuation coefficients as well as partial cross sections for the following processes: incoherent scattering, coherent scattering, photoelectric absorption, and pair production in the field of the atomic nucleus and in the field of the atomic electrons. For compounds, the quantities tabulated are partial and total mass interaction coefficients, which are equal to the product of the corresponding cross sections times the number of target molecules per unit mass of the material. The reciprocals of these interaction coefficients are the mean free paths between scatterings, between photo-electric absorption events, or between pair production events. The sum of the interaction coefficients for the individual processes is equal to the total attenuation coefficient. Total attenuation coefficients without the contribution from coherent scattering are also given, because they are often used in gamma-ray transport calculations.

The interaction coefficients and total attenuation coefficients for compounds or mixtures are obtained as sums of the corresponding quantities for the atomic constituents. The weighting factors, that is, the fractions by weight of the constituents, are calculated by XCOM from the chemical formula entered by the user. For mixtures, however, the user must supply the fractions by weight of the various components.

Some limitations should be noted. The cross sections for elements in the XCOM database pertain to isolated neutral atoms, and do not take into account molecular and solid-state effects which modify the cross sections, especially in the vicinity of absorption edges. Relatively small cross sections, such as those for Delbruck scattering, two-photon Compton scattering or photo-meson production, are not included. Also omitted is the nuclear photoeffect which, in the giant-dipole resonance region from 5 to $30 \mathrm{MeV}$, can contribute a few percent to the total attenuation coefficient. Finally, XCOM does not calculate energy absorption coefficients that represent the conversion of photon energy to kinetic energy of secondary Compton-, photo-, and pair-electrons.

\section{Database for Elements}

A comprehensive database for all elements over a wide range of energies was constructed through the combination of incoherent and coherent scattering cross sections from Refs. [12] and [13], photoelectric absorption from Scofield [14], and pair production cross sections from Ref. [8]. For scattering and pair production, the same cross sections are used as in other recent tabulations in Refs. $[6,8$, and 11], whereas for photoelectric absorption there is a small difference (omission of a renormalization correction) which is discussed below. 
The incoherent (Compton) scattering cross sections in Ref. [12] were obtained from a combination of the Klein-Nishina formula and nonrelativistic Hartree-Fock incoherent scattering functions. Radiative and double Comptonscattering corrections were also included. The coherent (Rayleigh) scattering cross sections in Ref. [13] were calculated from a combination of the Thompson formula and relativistic Hartree-Fock atomic form factors. The photoelectric cross sections were obtained by Scofield [14] by a phase-shift calculation for a central potential and a Hartree-Slater atomic model. Scofield's results extend only up to $1.5 \mathrm{MeV}$. At higher energies, where the photoelectric cross section is quite small, a semi-empirical formula from Ref. [2] connects Scofield's values at $1.5 \mathrm{MeV}$ to the asymptotic high-energy limit calculated by Pratt [15]. Cross sections for pair production given in Ref. [8] are based on complicated combinations of formulas from BetheHeitler theory with various other theoretical models to take into account screening, Coulomb, and radiative corrections. Different combinations were used in the near-threshold, intermediate and high-energy regions to obtain the best possible agreement with experimental cross sections.

For elements with atomic numbers from 2 to 54, Scofield [14] presented correction factors for individual atomic subshells, with which the photo-effect cross sections can be renormalized so that they correspond approximately to a relativistic Hartree-Fock model rather than the Hartreeslater model used in the original calculation. This renormalization is most significant for the outer atomic shells; the total cross section is lowered by no more than 10 percent at energies above $1 \mathrm{keV}$. Scofield did not actually apply the renormalization to the cross sections given in his tables. The renormalization was used, however, in the tabulations in Refs. [6, 8, and 11]. Recent reviews [16,17] indicate that, on the whole, agreement with experiment is better when the renormalization is not done. We have therefore omitted the renormalization in the database for the XCOM program.

\section{Interpolation and Combination}

For the purpose of interpolation with respect to photon energy, the coherent and incoherent scattering cross sections and the total attenuation coefficients are approximated by $\log -\log$ cubic-spline fits as functions of energy. For the pair-production cross sections, the fitted quantity is the logarithm of the quantity $\left(1-E / E^{\prime}\right)^{3} \sigma_{P A I R}(E)$, where $E$ is the photon energy, $E^{\prime}$ the threshold energy for pair production, and $\sigma_{\mathrm{PAIR}}(\mathrm{E})$ is the cross section. The fitting is done separately for pair production in the field of the atomic nucleus $\left(E^{\prime}=1.022 \mathrm{MeV}\right)$ and in the field of the atomic electrons $\left(E^{\prime}=2.044 \mathrm{MeV}\right)$.

The combined photoelectric absorption cross section for all shells is similarly interpolated with use of $\log -\log$ cubic-spline fits, but only at energies above the $\mathrm{K}$-shell absorption edge. Below this energy, interpolation is applied to the logarithm of the photoelectric absorption cross section for each separate shell, fitted as a linear function of the logarithm of the photon energy. The separate fitting for each shell is necessary to avoid the error that would be incurred by interpolating across absorption edges. Linear log-log fitting is equivalent to assuming that the photoelectric 
cross section is proportional to a power of the photon energy, and was found to provide more satisfactory fits than a $\log -\log$ cubic-spline fit near the absorption edges.

The interaction coefficients and total attenuation coefficients for compounds are obtained as weighted sums over the corresponding coefficients for elements. XCOM automatically calculates the weight factors, i.e., the fractions by weights of the atomic constituents, from the chemical formula for the compound entered by the user. For mixtures, the user must enter the fractions by weight of the components.

\section{Overview of the XCOM Program}

The hardware requirements for running the XCOM program are moderate. It is sufficient to have an IBM-compatible personal computer with a memory of at least $256 \mathrm{~K}$ bytes, and with at least one 5.25 -inch $360 \mathrm{kB}$ floppy-disk drive. It is assumed that the computer is operated with the PC-DOS or an MS-DOS operating system, version 2.0 or later. A mathematical co-processor (Intel 8087 or 80287 chip) is not required, but is highly desirable, because it speeds up the execution of XCOM by a factor of twenty or better.

The XCOM program is distributed on two 5.25-inch $360 \mathrm{kB}$ floppy disks. One of these is the Database Disk, and contains 100 data files designated as MDAT.001, MDAT.002,..., MDAT.100. These files, generated by a Fortran program and written in binary format, contain the cross-section database for the elements with atomic numbers $Z=1$ to 100 . The other disk is the Program Disk, and contains an executable file called XCOM.EXE.

The Program Disk also contains a copy of this report, in file XCOM.DOC, and the Fortran source code for XCOM. The source code is not needed to run $\mathrm{XCOM}$. It is included to make it possible for the user to make modify the program, and to adapt the program for use with a different operating system or computer.

The main program, XCOM, uses the following subroutines:

SPEC Allows the user to specify the composition of the material, the energy list, desired output etc.

FORM Translates the chemical symbols for elements or chemical formulas for compounds into the composition of the material specified in terms of atomic numbers, atomic weights, and fractions by weight of the atomic constituents.

MERGE Creates a merged energy list arranged according to magnitude. This list combines a standard energy grid (approximately logarithmic) with the set of absorption-edge energies for all the atomic constituents for a given compound or mixture, and with the set of additional energies which the user wishes to add. 
BSPOL Interpolation routine (based on binary search) making use of cubic-spline interpolation coefficients from SCOF.FOR.

BLIN Linear interpolation routine, based on binary search.

Also included on the Program Disk are five additional files which are "included" in the main program or in subroutines at the time of compilation. ENB.DAT and INDEX.DAT are for inclusion in XCOM, HASH1.DAT and HASH2.DAT in FORM, and ATWTS.DAT in XCOM and FORM.

\section{How to Run the XCOM Program}

If the program is to be run using only floppy disks, the Program Disk should be inserted into drive $A$. After the appearance of the $A>$ prompt, the program can be started by entering "XCOM".

If the program is to be run from a hard disk, it is recommended that a special subdirectory be created for running XCOM. First, the user should copy the file XCOM.EXE from the Program Disk and the data files MDAT.001, MDAT.002, ..., MDAT.100 from the Database Disk into the special directory. After the special directory is made the current directory, the program can be started by entering XCOM.

From this point on, the program proceeds interactively. The user must respond to prompts (indicated by -->) by entering requested input data or by making choices from various options. The requested information pertains to the name and characterization of the substance of interest, the desired set of energies at which cross sections are to be computed, and the form of the output.

The prompts are largely self-explanatory. In order to indicate to the user what to expect, we show in this report a record of prompts and responses that appeared on the monitor screen in three sample runs of XCOM, for an element (lead) in Appendix A, for a compound (calcium tungstate) in Appendix B, and for a mixture (pyrex glass) in Appendix C. The XCOM program could probably be run without further explanations. Additional information is provided in the remainder of this section, which will help the user to formulate his responses to the prompts.

\subsection{Name of Substance.}

The name can be freely chosen, may include imbedded blanks, and must consist of no more than 72 characters. The name will appear on the top of the output table. 


\subsection{Elements, Compounds and Mixtures.}

The substance for which cross sections are to be computed can be designated to be an element, compound or mixture. Elements can optionally be indicated by their atomic number, or by their chemical symbol. These symbols, or chemical formulas for compounds, should be entered in standard chemical notation, with appropriate upper and lower case. However, because of hardware limitations, subscripts must be written on line. For example, the formula for calcium tungstate must be entered as CaW04.

Substances consisting of molecules with only a single species of atoms can be designated as either elements or compounds. For example, molecular nitrogen could be treated as an "element" with symbol $\mathrm{N}$, or as a compound with formula $\mathrm{N}_{2}$ (entered as $\mathrm{N} 2$ ).

\subsection{Mixtures.}

Mixtures are assumed to consist of two or more components, each of which can be either an element or a compound. Whether the mixture is broken down into "elemental" components or "compound" components is a matter of convenience (depending on the readily available information), but does not change the results.

The user must indicate how many components there are in the mixture, and must specify the chemical symbol or formula, as well as the fraction by weight, for each component, as prompted. The program then uses these input data to compute the fractions by weight of the individual atomic constituents, as well as the sum of these fractions. This information is displayed on the monitor screen. The input data might be faulty in the sense that the sum of the fractions by weight does not add up to unity. In this case the user is given two choices: 1) The input data can be "accepted", in which case the program renormalizes all of the fractions by weight so that they add up to unity; 2) Another set of fractions by weight for the mixture can be entered.

\subsection{Quantities and Units.}

For elements, the user is given three choices: 1) the output can consist of cross sections for individual processes, and total cross sections, in units of barns/atom, where 1 barn $=10^{-24} \mathrm{~cm}^{2} ; 2$ ) the output can consist of cross sections for individual processes, in barns/atom, and mass attenuation coefficients, in $\mathrm{cm}^{2} / \mathrm{g} ; 3$ ) the output can consist of partial mass interaction coefficients and, total mass attenuation coefficients, in $\mathrm{cm}^{2} / \mathrm{g}$. For compounds and mixtures the output always consists of partial mass interaction coefficients, and total attenuation coefficients, in $\mathrm{cm}^{2} / \mathrm{g}$.

\subsection{Energy List.}

The user can 1) limit the output to the standard energy grid, 2) add to the standard grid selected energies of his choice, or 3 ) request output only for the set of energies selected by him. In case 2) the additional energies 
are merged into the standard energy grid according to magnitude. In case 3 ), the energies will appear in the output table exactly in the sequence in which they were entered by the user.

If additional energies are entered by the user, this can be done, optionally, either from the keyboard, or from a previously prepared input file. This file (stored in any desired directory on a floppy or hard disk) should contain, as first item, the number of additional energies, and then a list of energies, which items separated by blank spaces.

\subsection{Database Input Data}

The program will prompt the user as to the location of the file containing the database files. The user can request that these data be read from a floppy disk drives (A or $B$ ), or from the current directory in the hard disk. Even when the program is run from the special directory on the hard disk, the data can still come from drives $A$ or $B$. If the data are to come from the hard disk, they must have been previously stored in the special directory, i.e., the current directory from which the XCOM run was started.

\subsection{Output Table}

The user is asked by a prompt where the file with the cross section table is to be stored. The file specification can include the letter of the drive, the subdirectory, and the file name. If the current directory on a hard disk is to be used, only the file name need be supplied. If the user wants to see the output table only on the monitor screen, the output file should be designated as "CON". If the user wants neither to inspect nor to save the output table (because only the output arrays discussed in section 5.8 are wanted), the output file should be designated as "NUL".

On the top of each page of the table the name of the substance is given, followed by a listing of the atomic numbers and fractions by weight of the atomic constituents. The main body of the table is supplied with enough headings to be self-explanatory. This left-most column gives the designations of the absorption edges ( $K, L 1, L 2, L 3, M 1, M 2, \ldots)$ as well as the atomic number $Z$ of the pertinent atomic constituent. Data for energies immediately below and above each edge, are given on two lines separated by a blank line. It should be noted that the standard energy grid automatically includes at least one other energy between any two successive absorption edges. For materials of low atomic number, there are no absorption edges above $1 \mathrm{keV}$, and the column indicating the names of edges is absent.

Typical output tables are shown in Table 1 (for an element, lead), in Table 2 (for a compound, calcium tungstate) and in Table 3 (for a mixture, pyrex glass: $0.807 \mathrm{SiO}_{2}, 0.129 \mathrm{~B}_{2} \mathrm{O}_{3}, 0.038 \mathrm{Na}_{2} \mathrm{O}, 0.022 \mathrm{Al}_{2} \mathrm{O}_{3}$, and $0.004 \mathrm{~K}_{2} \mathrm{O}$ by weight). On the top of each page, the name of the substance is given, followed by a listing of the atomic numbers and fractions by weight of the atomic constituents. Fig. 1 shows some of the results from Table 2, namely, the total mass attenuation coefficient plotted as a function of the photon energy. 


\subsection{Additional Output Arrays}

The cross section tables described in Section 5.7 are directly comparable in format to printed tables found in the literature, and are most convenient for visual inspection of the data. If these data are to be used in subsequent computer calculations, the appropriate cross section arrays must be extracted for the tables. XCOM provides an option which fac1litates this task.

After the production of the cross section table is completed, the program prompts the user to indicate whether additional output in the form of arrays of selected quantities is desired. If the answer is affirmative, a selection menu is presented. The arrays which can be selected correspond to the columns in the cross section table. After each selection, this menu is presented again.

The user is also asked to provide the name of the file in which the additional arrays are to be stored. At the beginning of this file, preceding the arrays, the following information is stored. The first record consists of the name of the substance. The second record gives the number of atomic constituents, the third contains a list of atomic numbers of the constituents and the fourth a list of fractions by weight.

The fifth record gives the number of sub-arrays into which each array is divided, and the sixth contains the lengths of all successive sub-arrays. Each sub-array contains data for all energies between two adjacent absorption edges. This partitioning facilitates the setting up of interpolation schemes in which interpolation across absorption edges is avoided.

Subsequent records contain, for each of the quantities selected, an identifier (such as "energy list," "total attenuation coefficient") followed by one or more sub-arrays.

Even though the arrangement of the file, as described above, may appear somewhat complicated, it can easily be understood by comparison with the corresponding output table. A typical set of output arrays, consisting of photon energies and total mass attenuation coefficients for calcium tungstate, is given Table 4. These arrays are the same as the data in columns 2 and 7 in Table 2, and were used to produce the plot in Fig. 1.

Acknowledgement

This work was supported by the NBS Office of Standard Reference Data, and by the U.S. Department of Energy (OHER). 


\section{References}

1. Hubbell, J.H. and Berger, M.J., Sections 4.1 and 4.2 in Jaeger, R.G. (ed.): Engineering Compendium on Radiation Shielding (IAEA, Vienna), Vol. 1, Ch. 4, pp. 167-202, Springer, Berlin (1968).

2. Hubbell, J.H., Photon Cross Sections, Attenuation Coefficients and Energy Absorption Coefficients from $10 \mathrm{keV}$ to $100 \mathrm{GeV}$, Natl. Stand. Ref. Data Ser. 29 (1969).

3. McMaster, W.H., Del Grande, N.K.,Mallett, J.H, and Hubbell, J.H. Compilation of X-ray Cross Sections, Lawrence Livermore Lab., Report UCRL-50174, (1969).

4. Storm, E. and Israel, H.I., Photon Cross Sections from $1 \mathrm{keV}$ to $100 \mathrm{MeV}$ for Elements $Z=1$ to $Z=100$, Nucl. Data Tables A7, 565-681 (1970).

5. Veigele, W.J., Photon Cross Sections from $0.1 \mathrm{keV}$ to $1 \mathrm{MeV}$ for Elements $\mathrm{Z}=1$ to $\mathrm{Z}=94$, Atomic Data $\underline{5}, 51-111$ (1973).

6. Hubbell, J.H., Photon Mass Attenuation and Mass Energy-Absorption Coefficients for $\mathrm{H}, \mathrm{C}, \mathrm{N}, \mathrm{O}, \mathrm{Ar}$ and Seven Mixtures from $0.1 \mathrm{keV}$ to $20 \mathrm{MeV}$, Radiat. Res. 70, 58-81 (1977).

7. Leroux, J, and Thinh, T.P., Revised Tables of X-ray Mass Attenuation Coefficients, Corporation Scientifique Classique, Quebec (1977).

8. Hubbell, J.H., Gimm., H.A., and Overbo, I., Pair, Triplet and Total Atomic Cross Sections (and Mass Attenuation Coefficients) for $1 \mathrm{MeV}-100$ $\mathrm{GeV}$ Photons in Elements $\mathrm{Z}=1$ to 100 , J. Phys. Chem. Ref. Data 9, 1023-1147 (1980).

9. Plechaty, E.F., Cullen, D.E., and Howerton, R.J., Tables and Graphs of Photon-Interaction Cross Sections from $0.1 \mathrm{keV}$ to $100 \mathrm{MeV}$ Derived from the LLL Evaluated-Nuclear-Data Library, Report UCRL-50400, Vol. 6, Rev. 3 (1981).

10. Henke, B.L., Lee, P., Tanaka, T.J., Shimabukuro, R.L. and Fujikawa, B.K., Low Energy X-ray Interaction Coefficients: Photoabsorption, Scattering and Reflection, Atomic Data and Nuclear Data Tables, 27,1-144 (1982).

11. Hubbell, J.H., Photon Mass Attenuation and Energy Absorption Coefficients from $1 \mathrm{keV}$ to $20 \mathrm{MeV}$, Int. J. Appl. Radiation \& Isotopes, 33, 1269-1290 (1982).

12. Hubbell, J.H., Veigele, W.J., Briggs, E.A., Brown, R.T., Cromer, D.T., and Howerton, R.J., Atomic Form Factors, Incoherent Scattering Functions, and Photon Scattering Cross Sections, J. Phys. Chem. Ref. Data 4, 471-538 (1975); erratum in $\underline{6}, 615-616$ (1977). 
13. Hubbell, J.H. and Overbo, Relativistic Atomic Form Factors and Photon Coherent Scattering Cross Sections, J. Phys. Chem. Ref. Data $\underline{8}$, 69-105, (1979).

14. Scofield, J.H., Theoretical Photolonization Cross Sections from 1 to $1500 \mathrm{keV}$, Lawrence LIvermore Nat1onal Laboratory Rep. UCRL-51326 (1973).

15. Pratt, R.H., Atomic Photoelectric Effect at High Energies, Phys. Rev. 117, 1017-1028 (1960).

16. Saloman, E.B. and Hubbell, J.H., Critical Analysis of Soft X-ray Cross Section Data, Nucl. Instr. Meth. A255, 38-42 (1987).

17. E.B. Saloman and J.H.Hubbell, X-ray Attenuation Coefficients (Total Cross Sections): Comparison of the Experimental Data Base with Recommended Values of Henke and the Theoretical Values of Scofield for Energies between 0.1-100 keV, National Bureau of Standards Report NBSIR 86-3431 (1986). 


\section{$\mathrm{C}: \backslash \mathrm{xc}>\mathrm{XCOM}$}

Program XCOM (Version 1.2)

M. J. Berger, 9 MAY 1987

Enter name of substance $>$ Lead

Options for characterization of substance:

1. Elemental substance, specified by atomic number

2. Elemental substance, specified by chemical symbol

3. Compound, specified by chemical formula

4. Mixture of elements and/or compounds

Enter desired option $(1,2,3$ or 4$)-->1$

Enter atomic number of element $-->82$

Options for output quantities:

1. Cross sections in barns/atom

2. Cross sections in barns/atom, and attenuation coefficients in $\mathrm{cm} 2 / \mathrm{g}$

3. Partial interaction coefficients and attenuation coefficients in $\mathrm{cm} 2 / \mathrm{g}$

Enter desired option (1, 2 or 3$)-->2$

Options for energy list for output data:

1. Standard energy grid only

2. Standard grid plus additional energies

3. Additional energies only

Enter option desired $(1,2$ or 3$)-->2$

Modes of entering additional energies:

1. Entry from keyboard

2. Entry from prepared input file

Enter option desired ( 1 or 2 ) $-->1$

How many additional energies are wanted? --> 3

Enter first energy (in $\mathrm{MeV}$ ) $-->1.33$

Enter next energy (in MeV) --> 1.17

Enter next energy (in MeV) $->0.66$

Options for entry of Database files:

1. Read files from floppy-disk drive A

2. Read files from floppy-disk drive B

3. Read files from CURRENT directory on hard disk

Enter desired option (1,2, or 3 ). If necessary 
insert Database Disk into floppy-disk drive

before pressing "enter" --> 3

Specify file on which output (cross section table)

is to be stored. Specification can include drive and

path. If necessary, insert floppy disk into selected

drive before pressing "enter" --> OUT.082

Cross-section table with headings has been stored on file OUT.082

Options for further output:

1. No more output

2. Selected arrays stored on disk

Select option 1 or $2-->1$

Calculation is finished.

$C: \backslash x c>F F$ 


\section{APPENDIX B}

\section{$\mathrm{C}: \backslash \mathrm{xc}>\mathrm{XCOM}$}

Program XCOM (Version 1.2)

M. J. Berger, 9 MAY 1987

Enter name of substance $>$ Calcium Tungstate

Options for characterization of substance:

1. Elemental substance, specified by atomic number

2. Elemental substance, specified by chemical symbol

3. Compound, specified by chemical formula

4. Mixture of elements and/or compounds

Enter desired option $(1,2,3$ or 4$) \rightarrow->3$

Enter chemical formula for compound --> CaW04

Options for energy list for output data:

1. Standard energy grid only

2. Standard grid plus additional energies

3. Additional energies only

Enter option desired $(1,2$ or 3$)-\rightarrow 1$

Options for entry of Database files:

1. Read files from floppy-disk drive $A$

2. Read files from floppy-disk drive $B$

3. Read files from CURRENT directory on hard disk

Enter desired option (1,2, or 3$)$. If necessary

insert Database Disk into floppy-disk drive

before pressing "enter" --> 1

Specify file on which output (cross section table)

is to be stored. Specification can include drive and

path. If necessary, insert floppy disk into selected

drive before pressing "enter" --> B:OUT.CT1

Cross-section table with headings has been stored on file B:OUT.CT1

Options for further output:

1. No more output

2. Selected arrays stored on disk

Select option 1 or $2-->2$

Specify file on which selected arrays are to be stored.

Specification can include drive and path.

If necessary, insert floppy disk into selected drive

before pressing "enter" --> B:OUT.CT2

Options for array to be stored on on disk:

0 . Quit

1. Energy 1ist 


\section{APPENDIX B (Continued)}

2. Coherent scattering cross section

3. Incoherent scattering cross section

4. Photoelectric absorption cross section

5. Pair prod. cross section (atomic nucleus)

6. Pair prod. cross section (atomic electrons)

7. Total attenuation coeff. (or cross section)

8. Attenuation coeff. (or cross section) without contribution from coherent scattering

$$
\text { Select option }-->1
$$

Make next selection or quit.

Options for array to be stored on on disk:

0 . Quit

1. Energy list

2. Coherent scattering cross section

3. Incoherent scattering cross section

4. Photoelectric absorption cross section

5. Pair prod. cross section (atomic nucleus)

6. Pair prod. cross section (atomic electrons)

7. Total attenuation coeff. (or cross section)

8. Attenuation coeff. (or cross section) without contribution from coherent scattering

$$
\text { Select option }-->7
$$

Make next selection or quit.

Options for array to be stored on on disk:

0 . Quit

1. Energy list

2. Coherent scattering cross section

3. Incoherent scattering cross section

4. Photoelectric absorption cross section

5. Pair prod. cross section (atomic nucleus)

6. Pair prod. cross section (atomic electrons)

7. Total attenuation coeff. (or cross section)

8. Attenuation coeff. (or cross section)

without contribution from coherent scattering

$$
\text { Select option }-->0
$$

Selected cross section arrays have been stored on file B:OUT.CT2 Calculation is finished.

$C: \backslash \mathrm{xC}>\mathrm{FF}$ 


\section{$\mathrm{C}: \backslash \mathrm{xc}>\mathrm{XCOM}$}

Program XCOM (Version 1.2)

M. J. Berger, 9 MAY 1987

Enter name of substance > Pyrex Glass

Options for characterization of substance:

1. Elemental substance, specified by atomic number

2. Elemental substance, specified by chemical symbol

3. Compound, specified by chemical formula

4. Mixture of elements and/or compounds

Enter desired option $(1,2,3$ or 4$)-->4$

How many components in mixture? Enter number $-->5$

Enter chemical symbol or formula for component 1--> Sio2

Enter fraction by weight for component $1-->0.807$

Enter chemical symbol or formula for component 2--> B203

Enter fraction by weight for component 2--> 0.129

Enter chemical symbol or formula for component $3-->\mathrm{Na} 20$

Enter fraction by weight for component $3-->0.038$

Enter chemical symbol or formula for component 4--> A1203

Enter fraction by weight for component $4-->0.022$

Enter chemical symbol or formula for component $5-->\mathrm{K} 20$

Enter fraction by weight for component $5-->0.004$

Component Fraction

by Weight

$\begin{array}{lll}1 & 0.807000 & \mathrm{SiO2} \\ 2 & 0.129000 & \mathrm{~B} 203 \\ 3 & 0.038000 & \mathrm{Na} 20 \\ 4 & 0.022000 & \mathrm{~A} 1203 \\ 5 & 0.004000 & \mathrm{~K} 2 \mathrm{O}\end{array}$

Sum $=\quad 1.000000$

Options for accepting or rejecting composition data:

1. Accept, but let program normalize fractions by weight so that their sum is unity

2. Reject, and enter different set of fractions

Enter desired option ( 1 or 2 ) $-->1$ 


\section{APPENDIX C (Continued)}

Options for energy list for output data:

1. Standard energy grid only

2. Standard grid plus additional energies

3. Additional energies only

Enter option desired $(1,2$ or 3$)-->3$

Modes of entering additional energies:

1. Entry from keyboard

2. Entry from prepared input file

Enter option desired ( 1 or 2 ) $-->1$

How many additional energies are wanted? $-->5$

Enter first energy (in $\mathrm{MeV}$ ) $\quad-->0.0804$

Enter next energy (in MeV) $\rightarrow 0.2790$

Enter next energy (in $\mathrm{MeV}$ ) $-->0.6616$

Enter next energy (in MeV) - -> 1.3685

Enter next energy (in MeV) $-\rightarrow 2.7541$.

Options for entry of Database files:

1. Read files from floppy-disk drive A

2. Read files from floppy-disk drive B

3. Read files from CURRENT directory on hard disk

Enter desired option (1,2, or 3). If necessary

insert Database Disk into floppy-disk drive

before pressing "enter" - -> 3

Specify file on which output (cross section table)

is to be stored. Specification can include drive and

path. If necessary, insert floppy disk into selected

drive before pressing "enter" --> out.pyr

Cross-section table with headings has been stored on file out.pyr

Options for further output:

1. No more output

2. Selected arrays stored on disk

Select option 1 or $2-->1$

Calculation is finished.

$C: \backslash x c>f f$ 


\section{Table 1}

Lead

Constituents (Atomic Number:Fraction by Weight)

$82: 1.00000$

Cross Sections and Attenuation Coefficients

(Note that $1 \mathrm{~b}(\mathrm{arn})=10 * *(-24) \mathrm{cm} 2$ )

$\begin{array}{cccccccc}\text { PHOTON } & \text { SCATTERING } & \text { PHOTO- } & \text { PAIR PRODUCTION } & \text { TOTAL ATTENUATION } \\ \text { ENERGY } & \text { COHERENT INCOHER. ELECTRIC } & \text { IN } & \text { IN } & \text { WITH } & \text { WITHOUT } \\ & & \text { ABSORPTION NUCLEAR ELECTRON } & \text { COHERENT } & \text { COHERENT } \\ & & \text { FIELD } & \text { FIELD } & \text { SCATT. } & \text { SCATT. } \\ (\mathrm{MeV}) & (\mathrm{b} / \text { atom }) & (\mathrm{b} / \mathrm{atom}) & (\mathrm{b} / \mathrm{atom}) & (\mathrm{b} / \mathrm{atom}) & (\mathrm{b} / \mathrm{atom}) & (\mathrm{cm} 2 / \mathrm{g}) & (\mathrm{cm} 2 / \mathrm{g})\end{array}$

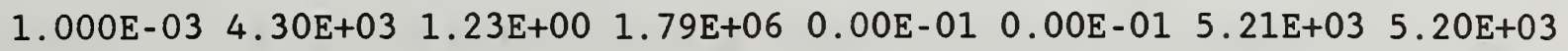

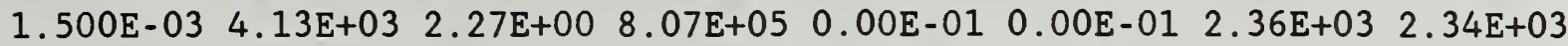

$\begin{array}{llllllllll}2.000 E-03 & 3.93 E+03 & 3.31 E+00 & 4.38 E+05 & 0.00 E-01 & 0.00 E-01 & 1.29 E+03 & 1.27 E+03\end{array}$

$\begin{array}{llllllll}2.484 E-03 & 3.74 E+03 & 4.27 E+00 & 2.72 E+05 & 0.00 E-01 & 0.00 E-01 & 8.01 E+02 & 7.90 E+02\end{array}$

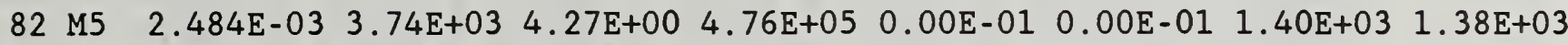

$\begin{array}{llllllllll}2.534 \mathrm{E}-03 & 3.72 \mathrm{E}+03 & 4.36 \mathrm{E}+00 & 5.63 \mathrm{E}+05 & 0.00 \mathrm{E}-01 & 0.00 \mathrm{E}-01 & 1.65 \mathrm{E}+03 & 1.64 \mathrm{E}+03\end{array}$

$2.586 \mathrm{E}-03 \quad 3.70 \mathrm{E}+03 \quad 4.46 \mathrm{E}+00 \quad 6.65 \mathrm{E}+05 \quad 0.00 \mathrm{E}-01 \quad 0.00 \mathrm{E}-01 \quad 1.94 \mathrm{E}+03 \quad 1.93 \mathrm{E}+03$

$82 \mathrm{M} 4 \quad 2.586 \mathrm{E}-03 \quad 3.70 \mathrm{E}+03 \quad 4.46 \mathrm{E}+00 \quad 8.39 \mathrm{E}+05 \quad 0.00 \mathrm{E}-01 \quad 0.00 \mathrm{E}-01 \quad 2.45 \mathrm{E}+03 \quad 2.44 \mathrm{E}+03$

$\begin{array}{llllllllll}3.000 E-03 & 3.53 E+03 & 5.25 E+00 & 6.72 E+05 & 0.00 E-01 & 0.00 E-01 & 1.96 E+03 & 1.95 E+03\end{array}$

3.066E-03 3.51E+03 5.37E+00 6.35E+05 $0.00 \mathrm{E}-01 \quad 0.00 \mathrm{E}-01 \quad 1.86 \mathrm{E}+03 \quad 1.85 \mathrm{E}+03$

$\begin{array}{lllllllll}82 \mathrm{M} 3 & 3.066 \mathrm{E}-03 & 3.51 \mathrm{E}+03 & 5.37 \mathrm{E}+00 & 7.35 \mathrm{E}+05 & 0.00 \mathrm{E}-01 & 0.00 \mathrm{E}-01 & 2.15 \mathrm{E}+03 & 2.14 \mathrm{E}+03\end{array}$

$\begin{array}{lllllllll}3.301 E-03 & 3.42 E+03 & 5.79 E+00 & 6.13 E+05 & 0.00 E-01 & 0.00 E-01 & 1.79 E+03 & 1.78 E+03\end{array}$

$\begin{array}{llllllll}3.554 \mathrm{E}-03 & 3.32 \mathrm{E}+03 & 6.24 \mathrm{E}+00 & 5.11 \mathrm{E}+05 & 0.00 \mathrm{E}-01 & 0.00 \mathrm{E}-01 & 1.50 \mathrm{E}+03 & 1.49 \mathrm{E}+03\end{array}$

82 M2 3.554E-03 $3.32 \mathrm{E}+03 \quad 6.24 \mathrm{E}+00 \quad 5.42 \mathrm{E}+05 \quad 0.00 \mathrm{E}-01 \quad 0.00 \mathrm{E}-01 \quad 1.58 \mathrm{E}+03 \quad 1.58 \mathrm{E}+03$

$\begin{array}{lllllllll}3.699 E-03 & 3.27 E+03 & 6.49 E+00 & 4.93 E+05 & 0.00 E-01 & 0.00 E-01 & 1.44 E+03 & 1.43 E+03\end{array}$

$\begin{array}{lllllllll}3.851 E-03 & 3.21 E+03 & 6.75 E+00 & 4.48 E+05 & 0.00 E-01 & 0.00 E-01 & 1.31 E+03 & 1.30 E+03\end{array}$

$82 \mathrm{M} 1 \quad 3.851 \mathrm{E}-03 \quad 3.21 \mathrm{E}+03 \quad 6.75 \mathrm{E}+00 \quad 4.67 \mathrm{E}+05 \quad 0.00 \mathrm{E}-01 \quad 0.00 \mathrm{E}-01 \quad 1.37 \mathrm{E}+03 \quad 1.36 \mathrm{E}+03$

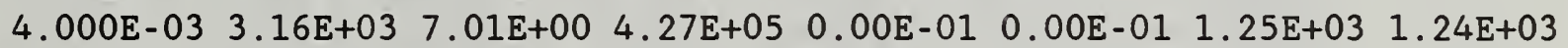

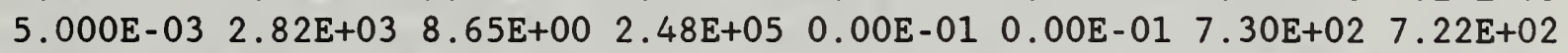
$\begin{array}{lllllllll}6.000 \mathrm{E}-03 & 2.53 \mathrm{E}+03 & 1.02 \mathrm{E}+01 & 1.58 \mathrm{E}+05 & 0.00 \mathrm{E}-01 & 0.00 \mathrm{E}-01 & 4.67 \mathrm{E}+02 & 4.60 \mathrm{E}+02\end{array}$

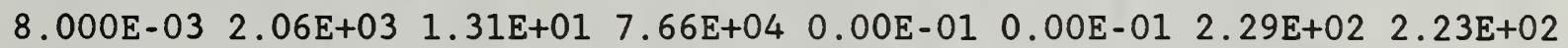
$\begin{array}{lllllllll}1.000 E-02 & 1.71 E+03 & 1.56 E+01 & 4.32 E+04 & 0.00 E-01 & 0.00 E-01 & 1.31 E+02 & 1.26 E+02\end{array}$ $\begin{array}{llllllllll}1.304 E-02 & 1.32 E+03 & 1.87 E+01 & 2.17 E+04 & 0.00 E-01 & 0.00 E-01 & 6.70 E+01 & 6.32 E+01\end{array}$

$82 \mathrm{~L} 3 \quad 1.304 \mathrm{E}-02 \quad 1.32 \mathrm{E}+03 \quad 1.87 \mathrm{E}+01 \quad 5.44 \mathrm{E}+04 \quad 0.00 \mathrm{E}-01 \quad 0.00 \mathrm{E}-01 \quad 1.62 \mathrm{E}+02 \quad 1.58 \mathrm{E}+02$ $\begin{array}{lllllllll}1.500 \mathrm{E}-02 & 1.14 \mathrm{E}+03 & 2.04 \mathrm{E}+01 & 3.72 \mathrm{E}+04 & 0.00 \mathrm{E}-01 & 0.00 \mathrm{E}-01 & 1.12 \mathrm{E}+02 & 1.08 \mathrm{E}+02\end{array}$ $\begin{array}{llllllllll}1.520 \mathrm{E}-02 & 1.12 \mathrm{E}+03 & 2.05 \mathrm{E}+01 & 3.59 \mathrm{E}+04 & 0.00 \mathrm{E}-01 & 0.00 \mathrm{E}-01 & 1.08 \mathrm{E}+02 & 1.05 \mathrm{E}+02\end{array}$

82 L2 $1.520 \mathrm{E}-02 \quad 1.12 \mathrm{E}+03 \quad 2.05 \mathrm{E}+01 \quad 5.00 \mathrm{E}+04 \quad 0.00 \mathrm{E}-01 \quad 0.00 \mathrm{E}-01 \quad 1.49 \mathrm{E}+02 \quad 1.45 \mathrm{E}+02$ $\begin{array}{llllllllll}1.553 \mathrm{E}-02 & 1.09 \mathrm{E}+03 & 2.08 \mathrm{E}+01 & 4.75 \mathrm{E}+04 & 0.00 \mathrm{E}-01 & 0.00 \mathrm{E}-01 & 1.41 \mathrm{E}+02 & 1.38 \mathrm{E}+02\end{array}$ $\begin{array}{llllllllllll}1.586 \mathrm{E}-02 & 1.07 \mathrm{E}+03 & 2.10 \mathrm{E}+01 & 4.51 \mathrm{E}+04 & 0.00 \mathrm{E}-01 & 0.00 \mathrm{E}-01 & 1.34 \mathrm{E}+02 & 1.31 \mathrm{E}+02\end{array}$

$\begin{array}{llllllllll}82 & \mathrm{~L} 1 & 1.586 \mathrm{E}-02 & 1.07 \mathrm{E}+03 & 2.10 \mathrm{E}+01 & 5.22 \mathrm{E}+04 & 0.00 \mathrm{E}-01 & 0.00 \mathrm{E}-01 & 1.55 \mathrm{E}+02 & 1.52 \mathrm{E}+02\end{array}$ $\begin{array}{llllllllll}2.000 E-02 & 8.04 E+02 & 2.37 \mathrm{E}+01 & 2.89 \mathrm{E}+04 & 0.00 \mathrm{E}-01 & 0.00 \mathrm{E}-01 & 8.64 \mathrm{E}+01 & 8.40 \mathrm{E}+01\end{array}$

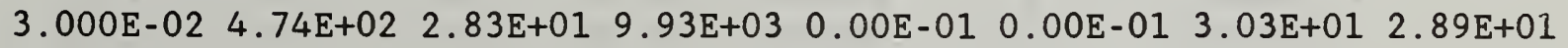
$\begin{array}{llllllllll}4.000 \mathrm{E}-02 & 3.17 \mathrm{E}+02 & 3.10 \mathrm{E}+01 & 4.59 \mathrm{E}+03 & 0.00 \mathrm{E}-01 & 0.00 \mathrm{E}-01 & 1.44 \mathrm{E}+01 & 1.34 \mathrm{E}+01\end{array}$ $\begin{array}{llllllll}5.000 \mathrm{E}-02 & 2.25 \mathrm{E}+02 & 3.26 \mathrm{E}+01 & 2.51 \mathrm{E}+03 & 0.00 \mathrm{E}-01 & 0.00 \mathrm{E}-01 & 8.04 \mathrm{E}+00 & 7.39 \mathrm{E}+00\end{array}$ $\begin{array}{lllllllll}6.000 E-02 & 1.69 E+02 & 3.35 E+01 & 1.52 E+03 & 0.00 E-01 & 0.00 E-01 & 5.02 E+00 & 4.53 E+00\end{array}$ $\begin{array}{llllllllll}8.000 E-02 & 1.06 E+02 & 3.41 E+01 & 6.92 E+02 & 0.00 E-01 & 0.00 E-01 & 2.42 E+00 & 2.11 E+00\end{array}$ 
Lead

Constituents (Atomic Number:Fraction by Weight) $82: 1.00000$

Cross Sections and Attenuation Coefficients (Note that $1 \mathrm{~b}(\mathrm{arn})=10 * *(-24) \mathrm{cm} 2$ )

PHOTON ENERGY

SCATTERING
COHERENT INCOHER.

PHOTOABSORPTION
PAIR PRODUCTION IN IN NUCLEAR ELECTRON

$(\mathrm{MeV})$

(b/atom)

(b/atom)

\begin{abstract}
(b/atom)
\end{abstract}
TOTAL ATTENUATION WITH WITHOUT COHERENT COHERENT SCATT. SCATT. $(\mathrm{cm} 2 / \mathrm{g}) \quad(\mathrm{cm} 2 / \mathrm{g})$

8.800E-02 9.06E+01 3.42E+01 5.32E+02 $0.00 E-01 \quad 0.00 E-01 \quad 1.91 E+00 \quad 1.65 E+00$

$\begin{array}{llllllll}8.800 E-02 & 9.06 E+01 & 3.42 E+01 & 2.52 E+03 & 0.00 E-01 & 0.00 E-01 & 7.68 E+00 & 7.42 E+00\end{array}$ $\begin{array}{llllllllll}1.000 E-01 & 7.32 E+01 & 3.40 E+01 & 1.80 E+03 & 0.00 E-01 & 0.00 E-01 & 5.55 E+00 & 5.34 E+00\end{array}$ $\begin{array}{llllllll}1.500 E-01 & 3.61 E+01 & 3.26 E+01 & 6.24 E+02 & 0.00 E-01 & 0.00 E-01 & 2.01 E+00 & 1.91 E+00\end{array}$

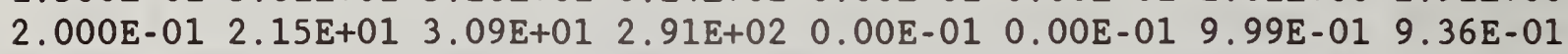

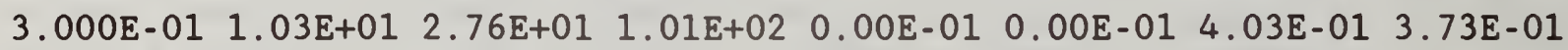
$\begin{array}{lllllllllll}4.000 E-01 & 6.01 E+00 & 2.51 E+01 & 4.88 E+01 & 0.00 E-01 & 0.00 E-01 & 2.32 E-01 & 2.15 E-01\end{array}$ $\begin{array}{llllllllll}5.000 E-01 & 3.93 E+00 & 2.32 E+01 & 2.84 E+01 & 0.00 E-01 & 0.00 E-01 & 1.61 E-01 & 1.50 E-01\end{array}$ $\begin{array}{llllllllllll}6.000 E-01 & 2.77 E+00 & 2.15 E+01 & 1.86 E+01 & 0.00 E-01 & 0.00 E-01 & 1.25 E-01 & 1.17 E-01\end{array}$

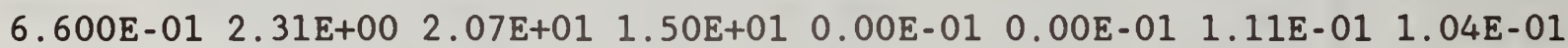
8.000E-01 1.59E+00 1.90E+01 9.88E+00 $0.00 E-01 \quad 0.00 E-01 \quad 8.87 E-02 \quad 8.41 E-02$ $\begin{array}{llllllll}1.000 E+00 & 1.03 E+00 & 1.72 E+01 & 6.23 E+00 & 0.00 E-01 & 0.00 E-01 & 7.10 E-02 & 6.80 E-02\end{array}$ $\begin{array}{lllllllll}1.022 \mathrm{E}+00 & 9.86 \mathrm{E}-01 & 1.70 \mathrm{E}+01 & 5.96 \mathrm{E}+00 & 0.00 \mathrm{E}-01 & 0.00 \mathrm{E}-01 & 6.96 \mathrm{E}-02 & 6.68 \mathrm{E}-02\end{array}$

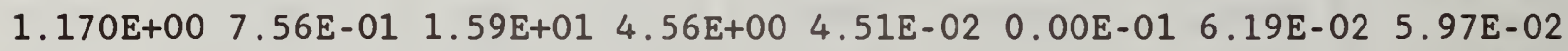

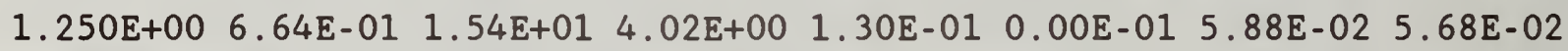
$\begin{array}{lllllllll}1.330 E+00 & 5.88 E-01 & 1.49 E+01 & 3.58 E+00 & 2.57 E-01 & 0.00 E-01 & 5.62 E-02 & 5.45 E-02\end{array}$ $\begin{array}{llllllll}1.500 E+00 & 4.64 E-01 & 1.40 E+01 & 2.86 E+00 & 6.22 E-01 & 0.00 E-01 & 5.22 E-02 & 5.09 E-02\end{array}$

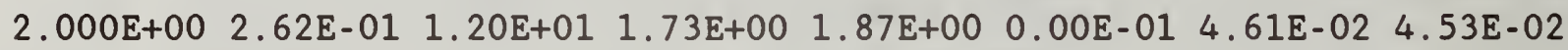
$2.044 E+00 \quad 2.51 E-01 \quad 1.18 E+01 \quad 1.67 E+00 \quad 1.99 E+00 \quad 0.00 E-01 \quad 4.58 E-02 \quad 4.50 E-02$

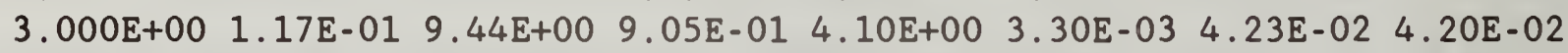

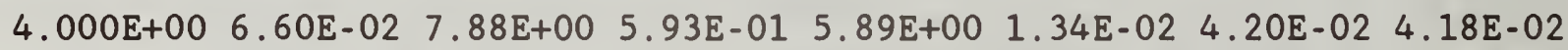

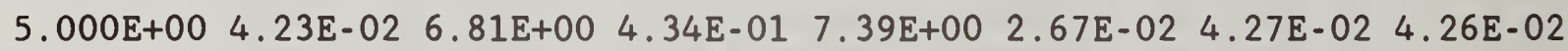
$\begin{array}{llllllll}6.000 E+00 & 2.94 \mathrm{E}-02 & 6.02 \mathrm{E}+00 & 3.40 \mathrm{E}-01 & 8.68 \mathrm{E}+00 & 4.10 \mathrm{E}-02 & 4.39 \mathrm{E}-02 & 4.38 \mathrm{E}-02\end{array}$

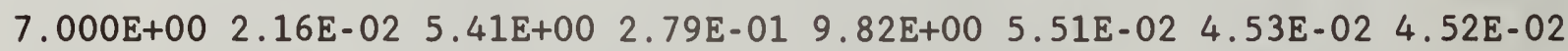
$\begin{array}{llllllll}8.000 \mathrm{E}+00 & 1.65 \mathrm{E}-02 & 4.92 \mathrm{E}+00 & 2.35 \mathrm{E}-01 & 1.08 \mathrm{E}+01 & 6.88 \mathrm{E}-02 & 4.67 \mathrm{E}-02 & 4.67 \mathrm{E}-02\end{array}$

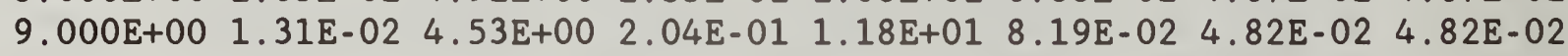
$\begin{array}{llllllll}1.000 E+01 & 1.06 E-02 & 4.19 E+00 & 1.79 E-01 & 1.26 E+01 & 9.43 E-02 & 4.97 E-02 & 4.97 E-02\end{array}$ $\begin{array}{llllllll}1.100 E+01 & 8.75 E-03 & 3.91 E+00 & 1.60 E-01 & 1.34 E+01 & 1.06 E-01 & 5.12 E-02 & 5.11 E-02\end{array}$ $\begin{array}{lllllllll}1.200 E+01 & 7.35 E-03 & 3.67 E+00 & 1.44 E-01 & 1.42 E+01 & 1.17 E-01 & 5.26 E-02 & 5.26 E-02\end{array}$ $\begin{array}{llllllll}1.300 \mathrm{E}+01 & 6.27 \mathrm{E}-03 & 3.46 \mathrm{E}+00 & 1.31 \mathrm{E}-01 & 1.49 \mathrm{E}+01 & 1.27 \mathrm{E}-01 & 5.40 \mathrm{E}-02 & 5.40 \mathrm{E}-02\end{array}$

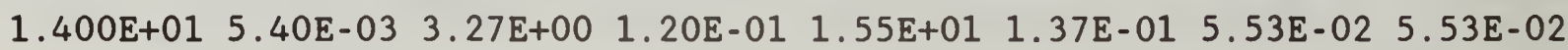
$\begin{array}{llllllll}1.500 \mathrm{E}+01 & 4.71 \mathrm{E}-03 & 3.10 \mathrm{E}+00 & 1.11 \mathrm{E}-01 & 1.61 \mathrm{E}+01 & 1.46 \mathrm{E}-01 & 5.66 \mathrm{E}-02 & 5.66 \mathrm{E}-02\end{array}$

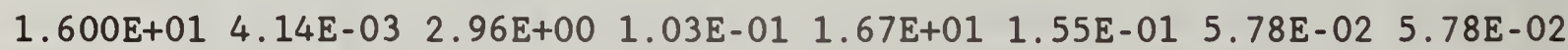

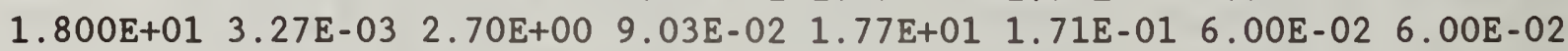
$\begin{array}{llllllll}2.000 \mathrm{E}+01 & 2.65 \mathrm{E}-03 & 2.49 \mathrm{E}+00 & 8.03 \mathrm{E}-02 & 1.86 \mathrm{E}+01 & 1.86 \mathrm{E}-01 & 6.21 \mathrm{E}-02 & 6.20 \mathrm{E}-02\end{array}$

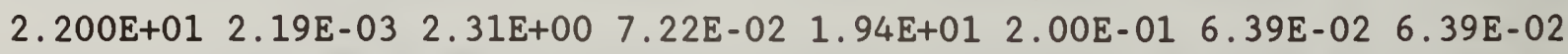
$\begin{array}{llllllll}2.400 \mathrm{E}+01 & 1.84 \mathrm{E}-03 & 2.16 \mathrm{E}+00 & 6.56 \mathrm{E}-02 & 2.02 \mathrm{E}+01 & 2.12 \mathrm{E}-01 & 6.57 \mathrm{E}-02 & 6.57 \mathrm{E}-02\end{array}$ $\begin{array}{llllllll}2.600 E+01 & 1.57 E-03 & 2.03 E+00 & 6.01 E-02 & 2.08 E+01 & 2.23 E-01 & 6.73 E-02 & 6.73 E-02\end{array}$

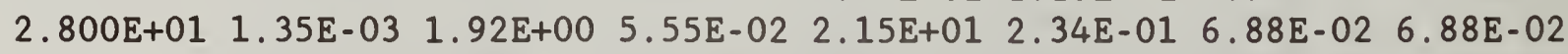
$\begin{array}{llllllll}3.000 E+01 & 1.18 \mathrm{E}-03 & 1.81 \mathrm{E}+00 & 5.15 \mathrm{E}-02 & 2.20 \mathrm{E}+01 & 2.44 \mathrm{E}-01 & 7.02 \mathrm{E}-02 & 7.02 \mathrm{E}-02\end{array}$ $\begin{array}{llllllll}4.000 E+01 & 6.62 E-04 & 1.44 E+00 & 3.79 E-02 & 2.44 E+01 & 2.84 E-01 & 7.61 E-02 & 7.61 E-02\end{array}$ $\begin{array}{llllllll}5.000 E+01 & 4.24 E-04 & 1.20 E+00 & 2.99 E-02 & 2.62 E+01 & 3.14 E-01 & 8.06 E-02 & 8.06 E-02\end{array}$ $\begin{array}{llllllll}6.000 E+01 & 2.94 E-04 & 1.04 E+00 & 2.47 E-02 & 2.75 E+01 & 3.37 E-01 & 8.41 E-02 & 8.41 E-02\end{array}$ 


\section{Table 1 (Continued)}

\section{Lead}

Constituents (Atomic Number:Fraction by Weight)

$82: 1.00000$

Cross Sections and Attenuation Coefficients

(Note that $1 \mathrm{~b}(\mathrm{arn})=10 * *(-24) \mathrm{cm} 2$ )

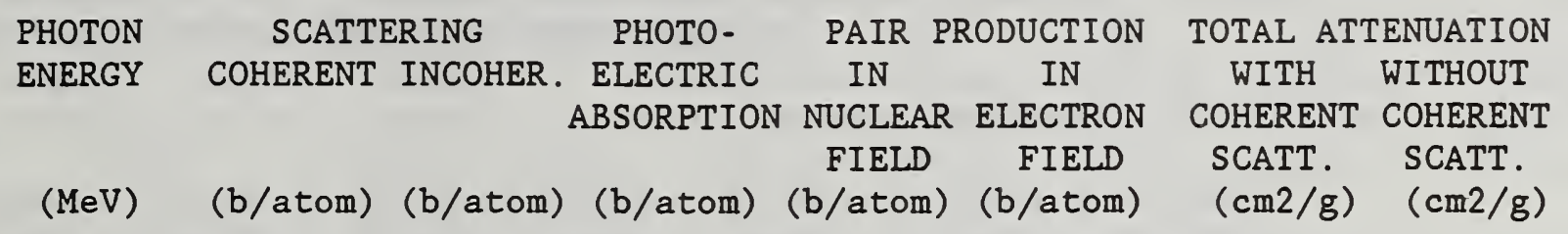

$\begin{array}{llllllll}8.000 \mathrm{E}+01 & 1.65 \mathrm{E}-04 & 8.18 \mathrm{E}-01 & 1.84 \mathrm{E}-02 & 2.95 \mathrm{E}+01 & 3.73 \mathrm{E}-01 & 8.93 \mathrm{E}-02 & 8.93 \mathrm{E}-02\end{array}$

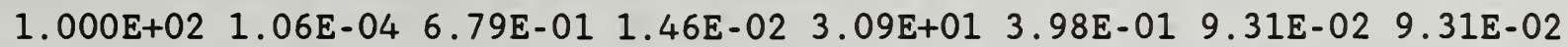

$\begin{array}{llllllll}1.500 \mathrm{E}+02 & 4.71 \mathrm{E}-05 & 4.83 \mathrm{E}-01 & 9.66 \mathrm{E}-03 & 3.32 \mathrm{E}+01 & 4.40 \mathrm{E}-01 & 9.91 \mathrm{E}-02 & 9.91 \mathrm{E}-02\end{array}$

$\begin{array}{lllllllll}2.000 \mathrm{E}+02 & 2.65 \mathrm{E}-05 & 3.79 \mathrm{E}-01 & 7.21 \mathrm{E}-03 & 3.45 \mathrm{E}+01 & 4.65 \mathrm{E}-01 & 1.03 \mathrm{E}-01 & 1.03 \mathrm{E}-01\end{array}$

$\begin{array}{lllllllll}3.000 \mathrm{E}+02 & 1.18 \mathrm{E}-05 & 2.69 \mathrm{E}-01 & 4.79 \mathrm{E}-03 & 3.60 \mathrm{E}+01 & 4.96 \mathrm{E}-01 & 1.07 \mathrm{E}-01 & 1.07 \mathrm{E}-01\end{array}$

$\begin{array}{lllllllll}4.000 \mathrm{E}+02 & 6.62 \mathrm{E}-06 & 2.10 \mathrm{E}-01 & 3.58 \mathrm{E}-03 & 3.69 \mathrm{E}+01 & 5.15 \mathrm{E}-01 & 1.09 \mathrm{E}-01 & 1.09 \mathrm{E}-01\end{array}$

$\begin{array}{lllllllll}5.000 \mathrm{E}+02 & 4.24 \mathrm{E}-06 & 1.74 \mathrm{E}-01 & 2.86 \mathrm{E}-03 & 3.75 \mathrm{E}+01 & 5.27 \mathrm{E}-01 & 1.11 \mathrm{E}-01 & 1.11 \mathrm{E}-01\end{array}$

$\begin{array}{lllllllll}6.000 \mathrm{E}+02 & 2.94 \mathrm{E}-06 & 1.49 \mathrm{E}-01 & 2.38 \mathrm{E}-03 & 3.79 \mathrm{E}+01 & 5.36 \mathrm{E}-01 & 1.12 \mathrm{E}-01 & 1.12 \mathrm{E}-01\end{array}$

8.000E $+02 \quad 1.66 \mathrm{E}-06$ 1.16E-01- $1.79 \mathrm{E}-03 \quad 3.84 \mathrm{E}+01 \quad 5.49 \mathrm{E}-01 \quad 1.14 \mathrm{E}-01 \quad 1.14 \mathrm{E}-01$

$\begin{array}{lllllllll}1.000 \mathrm{E}+03 & 1.06 \mathrm{E}-06 & 9.58 \mathrm{E}-02 & 1.43 \mathrm{E}-03 & 3.88 \mathrm{E}+01 & 5.57 \mathrm{E}-01 & 1.15 \mathrm{E}-01 & 1.15 \mathrm{E}-01\end{array}$

$\begin{array}{llllllll}1.500 \mathrm{E}+03 & 4.71 \mathrm{E}-07 & 6.69 \mathrm{E}-02 & 9.51 \mathrm{E}-04 & 3.93 \mathrm{E}+01 & 5.69 \mathrm{E}-01 & 1.16 \mathrm{E}-01 & 1.16 \mathrm{E}-01\end{array}$

$\begin{array}{lllllllll}2.000 \mathrm{E}+03 & 2.65 \mathrm{E}-07 & 5.18 \mathrm{E}-02 & 7.13 \mathrm{E}-04 & 3.96 \mathrm{E}+01 & 5.76 \mathrm{E}-01 & 1.17 \mathrm{E}-01 & 1.17 \mathrm{E}-01\end{array}$

$\begin{array}{lllllllll}3.000 \mathrm{E}+03 & 1.18 \mathrm{E}-07 & 3.60 \mathrm{E}-02 & 4.75 \mathrm{E}-04 & 3.99 \mathrm{E}+01 & 5.84 \mathrm{E}-01 & 1.18 \mathrm{E}-01 & 1.18 \mathrm{E}-01\end{array}$

$\begin{array}{lllllllll}4.000 \mathrm{E}+03 & 6.62 \mathrm{E}-08 & 2.78 \mathrm{E}-02 & 3.56 \mathrm{E}-04 & 4.00 \mathrm{E}+01 & 5.88 \mathrm{E}-01 & 1.18 \mathrm{E}-01 & 1.18 \mathrm{E}-01\end{array}$

$\begin{array}{llllllll}5.000 \mathrm{E}+03 & 4.24 \mathrm{E}-08 & 2.27 \mathrm{E}-02 & 2.85 \mathrm{E}-04 & 4.01 \mathrm{E}+01 & 5.91 \mathrm{E}-01 & 1.18 \mathrm{E}-01 & 1.18 \mathrm{E}-01\end{array}$

$6.000 \mathrm{E}+03 \quad 2.94 \mathrm{E}-08 \quad 1.93 \mathrm{E}-02 \quad 2.38 \mathrm{E}-04 \quad 4.02 \mathrm{E}+01 \quad 5.93 \mathrm{E}-01 \quad 1.19 \mathrm{E}-01 \quad 1.19 \mathrm{E}-01$

$8.000 \mathrm{E}+03 \quad 1.66 \mathrm{E}-08$ 1.48E-02 $1.78 \mathrm{E}-04 \quad 4.03 \mathrm{E}+01 \quad 5.95 \mathrm{E}-01 \quad 1.19 \mathrm{E}-01 \quad 1.19 \mathrm{E}-01$

$\begin{array}{llllllll}1.000 \mathrm{E}+04 & 1.06 \mathrm{E}-08 & 1.21 \mathrm{E}-02 & 1.42 \mathrm{E}-04 & 4.03 \mathrm{E}+01 & 5.97 \mathrm{E}-01 & 1.19 \mathrm{E}-01 & 1.19 \mathrm{E}-01\end{array}$

$\begin{array}{llllllll}1.500 \mathrm{E}+04 & 4.71 \mathrm{E}-09 & 8.38 \mathrm{E}-03 & 9.50 \mathrm{E}-05 & 4.04 \mathrm{E}+01 & 5.99 \mathrm{E}-01 & 1.19 \mathrm{E}-01 & 1.19 \mathrm{E}-01\end{array}$

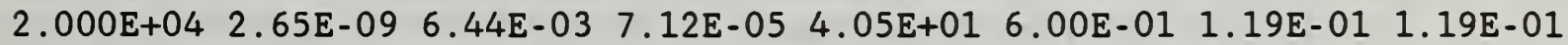

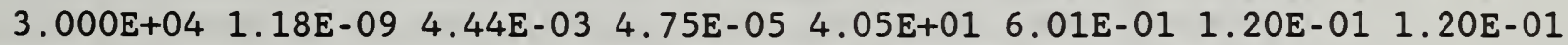

$\begin{array}{lllllllll}4.000 \mathrm{E}+04 & 6.62 \mathrm{E}-10 & 3.41 \mathrm{E}-03 & 3.56 \mathrm{E}-05 & 4.05 \mathrm{E}+01 & 6.02 \mathrm{E}-01 & 1.20 \mathrm{E}-01 & 1.20 \mathrm{E}-01\end{array}$

$\begin{array}{llllllll}5.000 \mathrm{E}+04 & 4.24 \mathrm{E}-10 & 2.78 \mathrm{E}-03 & 2.85 \mathrm{E}-05 & 4.05 \mathrm{E}+01 & 6.03 \mathrm{E}-01 & 1.20 \mathrm{E}-01 & 1.20 \mathrm{E}-01\end{array}$

$\begin{array}{lllllllll}6.000 \mathrm{E}+04 & 2.94 \mathrm{E}-10 & 2.35 \mathrm{E}-03 & 2.37 \mathrm{E}-05 & 4.06 \mathrm{E}+01 & 6.03 \mathrm{E}-01 & 1.20 \mathrm{E}-01 & 1.20 \mathrm{E}-01\end{array}$

8.000E +04 1.66E-10 $1.80 \mathrm{E}-03 \quad 1.78 \mathrm{E}-05 \quad 4.06 \mathrm{E}+01 \quad 6.03 \mathrm{E}-01 \quad 1.20 \mathrm{E}-01 \quad 1.20 \mathrm{E}-01$

$\begin{array}{llllllll}1.000 \mathrm{E}+05 & 1.06 \mathrm{E}-10 & 1.46 \mathrm{E}-03 & 1.42 \mathrm{E}-05 & 4.06 \mathrm{E}+01 & 6.03 \mathrm{E}-01 & 1.20 \mathrm{E}-01 & 1.20 \mathrm{E}-01\end{array}$ 
Table 2

Calcium Tungstate

Constituents (Atomic Number:Fraction by Weight)

$8: 0.22227 \quad 20: 0.13920 \quad 74: 0.63853$

Partial Interaction Coefficients and Total Attenuation Coefficients

PHOTON

ENERGY

SCATTERING

COHERENT INCOHER. ELECTRIC

ABSORPTION

$(\mathrm{MeV})$

$(\mathrm{cm} 2 / \mathrm{g}) \quad(\mathrm{cm} 2 / \mathrm{g}) \quad(\mathrm{cm} 2 / \mathrm{g})$

PAIR PRODUCTION

IN

IN

NUCLEAR ELECTRON
FIELD FIELD

$(\mathrm{cm} 2 / \mathrm{g})$

$(\mathrm{cm} 2 / \mathrm{g})$

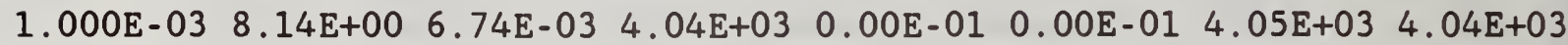

$1.500 \mathrm{E}-03 \quad 7.76 \mathrm{E}+00$ 1.20E-02 $1.62 \mathrm{E}+03 \quad 0.00 \mathrm{E}-01 \quad 0.00 \mathrm{E}-01 \quad 1.63 \mathrm{E}+03 \quad 1.62 \mathrm{E}+03$

$\begin{array}{lllllllll}1.809 \mathrm{E}-03 & 7.51 \mathrm{E}+00 & 1.53 \mathrm{E}-02 & 1.05 \mathrm{E}+03 & 0.00 \mathrm{E}-01 & 0.00 \mathrm{E}-01 & 1.06 \mathrm{E}+03 & 1.05 \mathrm{E}+03\end{array}$

74 M5 1.809E-03 7.51E+00 1.53E-02 $1.18 \mathrm{E}+03 \quad 0.00 \mathrm{E}-01 \quad 0.00 \mathrm{E}-01 \quad 1.19 \mathrm{E}+03 \quad 1.18 \mathrm{E}+03$

$\begin{array}{llllllll}1.840 \mathrm{E}-03 & 7.49 \mathrm{E}+00 & 1.56 \mathrm{E}-02 & 1.57 \mathrm{E}+03 & 0.00 \mathrm{E}-01 & 0.00 \mathrm{E}-01 & 1.57 \mathrm{E}+03 & 1.57 \mathrm{E}+03\end{array}$

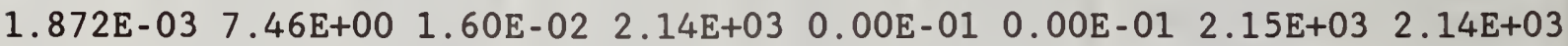

$\begin{array}{lllllllllllllll}74 & 1.872 \mathrm{E}-03 & 7.46 \mathrm{E}+00 & 1.60 \mathrm{E}-02 & 2.31 \mathrm{E}+03 & 0.00 \mathrm{E}-01 & 0.00 \mathrm{E}-01 & 2.31 \mathrm{E}+03 & 2.31 \mathrm{E}+03\end{array}$

$\begin{array}{llllllll}2.000 \mathrm{E}-03 & 7.35 \mathrm{E}+00 & 1.74 \mathrm{E}-02 & 2.76 \mathrm{E}+03 & 0.00 \mathrm{E}-01 & 0.00 \mathrm{E}-01 & 2.77 \mathrm{E}+03 & 2.76 \mathrm{E}+03\end{array}$

$\begin{array}{llllllll}2.281 \mathrm{E}-03 & 7.12 \mathrm{E}+00 & 2.04 \mathrm{E}-02 & 1.98 \mathrm{E}+03 & 0.00 \mathrm{E}-01 & 0.00 \mathrm{E}-01 & 1.99 \mathrm{E}+03 & 1.98 \mathrm{E}+03\end{array}$

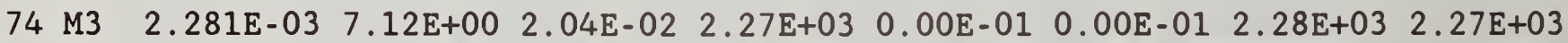

$\begin{array}{llllllll}2.423 \mathrm{E}-03 & 7.00 \mathrm{E}+00 & 2.19 \mathrm{E}-02 & 1.96 \mathrm{E}+03 & 0.00 \mathrm{E}-01 & 0.00 \mathrm{E}-01 & 1.96 \mathrm{E}+03 & 1.96 \mathrm{E}+03\end{array}$

$\begin{array}{lllllllll}2.575 E-03 & 6.89 E+00 & 2.35 E-02 & 1.69 E+03 & 0.00 E-01 & 0.00 E-01 & 1.69 E+03 & 1.69 E+03\end{array}$

$\begin{array}{llllllllllllll}74 & \text { M2 2.575E-03 } & 6.89 \mathrm{E}+00 & 2.35 \mathrm{E}-02 & 1.78 \mathrm{E}+03 & 0.00 \mathrm{E}-01 & 0.00 \mathrm{E}-01 & 1.79 \mathrm{E}+03 & 1.78 \mathrm{E}+03\end{array}$

$\begin{array}{lllllllll}2.694 \mathrm{E}-03 & 6.79 \mathrm{E}+00 & 2.48 \mathrm{E}-02 & 1.60 \mathrm{E}+03 & 0.00 \mathrm{E}-01 & 0.00 \mathrm{E}-01 & 1.61 \mathrm{E}+03 & 1.60 \mathrm{E}+03\end{array}$

$\begin{array}{llllllll}2.820 \mathrm{E}-03 & 6.69 \mathrm{E}+00 & 2.61 \mathrm{E}-02 & 1.44 \mathrm{E}+03 & 0.00 \mathrm{E}-01 & 0.00 \mathrm{E}-01 & 1.45 \mathrm{E}+03 & 1.44 \mathrm{E}+03\end{array}$

$\begin{array}{llllllllll}74 \mathrm{M} 1 & 2.820 \mathrm{E}-03 & 6.69 \mathrm{E}+00 & 2.61 \mathrm{E}-02 & 1.50 \mathrm{E}+03 & 0.00 \mathrm{E}-01 & 0.00 \mathrm{E}-01 & 1.50 \mathrm{E}+03 & 1.50 \mathrm{E}+03\end{array}$ $\begin{array}{llllllllll}3.000 \mathrm{E}-03 & 6.54 \mathrm{E}+00 & 2.80 \mathrm{E}-02 & 1.29 \mathrm{E}+03 & 0.00 \mathrm{E}-01 & 0.00 \mathrm{E}-01 & 1.30 \mathrm{E}+03 & 1.29 \mathrm{E}+03\end{array}$ $\begin{array}{llllllll}4.000 \mathrm{E}-03 & 5.80 \mathrm{E}+00 & 3.77 \mathrm{E}-02 & 6.42 \mathrm{E}+02 & 0.00 \mathrm{E}-01 & 0.00 \mathrm{E}-01 & 6.48 \mathrm{E}+02 & 6.43 \mathrm{E}+02\end{array}$ $\begin{array}{llllllll}4.038 \mathrm{E}-03 & 5.78 \mathrm{E}+00 & 3.80 \mathrm{E}-02 & 6.28 \mathrm{E}+02 & 0.00 \mathrm{E}-01 & 0.00 \mathrm{E}-01 & 6.33 \mathrm{E}+02 & 6.28 \mathrm{E}+02\end{array}$

$20 \mathrm{~K} \quad 4.038 \mathrm{E}-03 \quad 5.78 \mathrm{E}+00 \quad 3.80 \mathrm{E}-02 \quad 7.53 \mathrm{E}+02 \quad 0.00 \mathrm{E}-01 \quad 0.00 \mathrm{E}-01 \quad 7.59 \mathrm{E}+02 \quad 7.53 \mathrm{E}+02$ 5.000E-03 5.15E+00 4.62E-02 4.43E+02 $0.00 \mathrm{E}-01 \quad 0.00 \mathrm{E}-01 \quad 4.48 \mathrm{E}+02 \quad 4.43 \mathrm{E}+02$ $\begin{array}{lllllllll}6.000 \mathrm{E}-03 & 4.59 \mathrm{E}+00 & 5.35 \mathrm{E}-02 & 2.78 \mathrm{E}+02 & 0.00 \mathrm{E}-01 & 0.00 \mathrm{E}-01 & 2.82 \mathrm{E}+02 & 2.78 \mathrm{E}+02\end{array}$ 8.000E-03 3.69E+00 6.50E-02 $1.32 \mathrm{E}+02 \quad 0.00 \mathrm{E}-01 \quad 0.00 \mathrm{E}-01 \quad 1.35 \mathrm{E}+02 \quad 1.32 \mathrm{E}+02$ 1.000E-02 3.02E+00 7.36E-02 $7.31 \mathrm{E}+01 \quad 0.00 \mathrm{E}-01 \quad 0.00 \mathrm{E}-01 \quad 7.62 \mathrm{E}+01 \quad 7.32 \mathrm{E}+01$ 1.021E-02 2.96E+00 7.44E-02 6.92E+01 0.00E-01 0.00E-01 7.23E+01 6.93E+01

$\begin{array}{lllllllll}74 & \text { L3 1.021E-02 2.96E+00 7.44E-02 } & 1.60 \mathrm{E}+02 & 0.00 \mathrm{E}-01 & 0.00 \mathrm{E}-01 & 1.63 \mathrm{E}+02 & 1.60 \mathrm{E}+02\end{array}$ 1.085E-02 2.79E+00 7.67E-02 $1.35 \mathrm{E}+02 \quad 0.00 \mathrm{E}-01 \quad 0.00 \mathrm{E}-01 \quad 1.38 \mathrm{E}+02 \quad 1.35 \mathrm{E}+02$ 1.154E-02 2.62E+00 7.91E-02 1.15E+02 0.00E-01 $0.00 \mathrm{E}-01 \quad 1.17 \mathrm{E}+02 \quad 1.15 \mathrm{E}+02$

$\begin{array}{llllllll}74 & \text { L2 1.154E-02 2.62E+00 7.91E-02 1.55E+02 } & 0.00 \mathrm{E}-01 & 0.00 \mathrm{E}-01 & 1.57 \mathrm{E}+02 & 1.55 \mathrm{E}+02\end{array}$ $\begin{array}{llllllll}1.182 \mathrm{E}-02 & 2.56 \mathrm{E}+00 & 7.99 \mathrm{E}-02 & 1.46 \mathrm{E}+02 & 0.00 \mathrm{E}-01 & 0.00 \mathrm{E}-01 & 1.48 \mathrm{E}+02 & 1.46 \mathrm{E}+02\end{array}$ 1.210E-02 2.49E+00 8.08E-02 $1.38 \mathrm{E}+02 \quad 0.00 \mathrm{E}-01 \quad 0.00 \mathrm{E}-01 \quad 1.40 \mathrm{E}+02 \quad 1.38 \mathrm{E}+02$

$\begin{array}{lllllllll}74 \text { L1 1.210E-02 2.49E+00 8.08E-02 } & 1.58 \mathrm{E}+02 & 0.00 \mathrm{E}-01 & 0.00 \mathrm{E}-01 & 1.60 \mathrm{E}+02 & 1.58 \mathrm{E}+02\end{array}$ 1.500E-02 1.95E+00 8.87E-02 9.12E+01 0.00E-01 $0.00 \mathrm{E}-01 \quad 9.32 \mathrm{E}+01 \quad 9.13 \mathrm{E}+01$ 2.000E-02 1.38E+00 9.89E-02 4.25E+01 $0.00 \mathrm{E}-01 \quad 0.00 \mathrm{E}-01 \quad 4.40 \mathrm{E}+01 \quad 4.26 \mathrm{E}+01$ 3.000E-02 8.09E-01 1.11E-01 1.42E+01 0.00E-01 0.00E-01 1.52E+01 1.44E+01 
Table 2 (Continued)

Calcium Tungstate

Constituents (Atomic Number:Fraction by Weight)

$8: 0.22227 \quad 20: 0.13920 \quad 74: 0.63853$

Partial Interaction Coefficients and Total Attenuation Coefficients

PHOTON

ENERGY

$(\mathrm{MeV})$

4.000E-02 5.32E-01

SCATTERING

COHERENT INCOHER. ELECTRIC

ABSORPTION NUCLEAR ELECTRON

$5.000 \mathrm{E}-02$

(cm2/g)
$5.32 E-01$
$3.76 E-01$
$2.81 E-01$

$(\mathrm{cm} 2 / \mathrm{g}) \quad(\mathrm{cm} 2 / \mathrm{g})$

$(\mathrm{cm} 2 / \mathrm{g})$
FIELD

PAIR PRODUCTION

IN

FIELD

$(\mathrm{cm} 2 / \mathrm{g})$
TOTAL ATTENUATION

WITH WITHOUT

COHERENT COHERENT

SCATT.

$(\mathrm{cm} 2 / \mathrm{g})$

SCATT

$(\mathrm{cm} 2 / \mathrm{g})$

1.19E-01 3.49E+00 $0.00 \mathrm{E}-010.00 \mathrm{E}-013.99 \mathrm{E}+003.61 \mathrm{E}+00$

$6.000 \mathrm{E}-022.81 \mathrm{E}-01$ 1.20E-01 2.10E+00 0.00E-01 0.00E-01 2.50E+00 2.22E+00

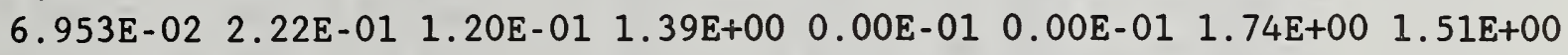

$74 \mathrm{~K}$

6.953E-02 2.22E-01 1.20E-01 6.94E+00 0.00E-01 $0.00 \mathrm{E}-01 \quad 7.28 \mathrm{E}+00 \quad 7.06 \mathrm{E}+00$

8.000E-02 1.76E-01 1.20E-01 4.78E+00 0.00E-01 $0.00 \mathrm{E}-01 \quad 5.07 \mathrm{E}+00 \quad 4.90 \mathrm{E}+00$

$\begin{array}{llllllll}1.000 \mathrm{E}-01 & 1.21 \mathrm{E}-01 & 1.17 \mathrm{E}-01 & 2.67 \mathrm{E}+00 & 0.00 \mathrm{E}-01 & 0.00 \mathrm{E}-01 & 2.90 \mathrm{E}+00 & 2.78 \mathrm{E}+00\end{array}$

$\begin{array}{llllllllll}1.500 \mathrm{E}-01 & 5.90 \mathrm{E}-02 & 1.10 \mathrm{E}-01 & 8.94 \mathrm{E}-01 & 0.00 \mathrm{E}-01 & 0.00 \mathrm{E}-01 & 1.06 \mathrm{E}+00 & 1.00 \mathrm{E}+00\end{array}$

2.000E-01 3.51E-02 1.02E-01 4.10E-01 0.00E-01 0.00E-01 5.48E-01 5.12E-01

3.000E-01 1.67E-02 9.07E-02 1.39E-01 0.00E-01 $0.00 \mathrm{E}-01 \quad 2.46 \mathrm{E}-01 \quad 2.29 \mathrm{E}-01$

4.000E-01 9.68E-03 8.20E-02 6.61E-02 0.00E-01 $0.00 \mathrm{E}-01 \quad 1.58 \mathrm{E}-01 \quad 1.48 \mathrm{E}-01$

5.000E-01 6.31E-03 7.52E-02 3.82E-02 0.00E-01 $0.00 \mathrm{E}-01$ 1.20E-01 $1.13 \mathrm{E}-01$

6.000E-01 4.44E-03 6.98E-02 2.48E-02 0.00E-01 $0.00 E-01 \quad 9.91 E-02 \quad 9.46 E-02$

8.000E-01 2.54E-03 6.16E-02 1.31E-02 0.00E-01 $0.00 \mathrm{E}-01 \quad 7.72 \mathrm{E}-02 \quad 7.46 \mathrm{E}-02$

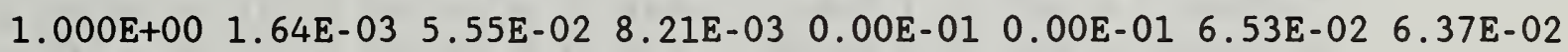

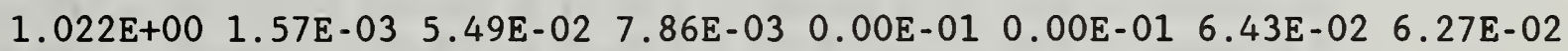

$\begin{array}{llllllll}1.250 E+00 & 1.06 E-03 & 4.96 E-02 & 5.30 E-03 & 2.18 E-04 & 0.00 E-01 & 5.62 E-02 & 5.52 E-02\end{array}$

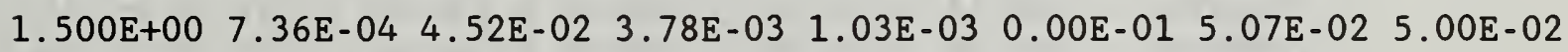

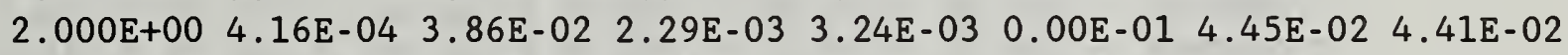

$\begin{array}{llllllll}2.044 E+00 & 3.98 E-04 & 3.81 E-02 & 2.21 E-03 & 3.44 E-03 & 0.00 E-01 & 4.41 E-02 & 4.37 E-02\end{array}$

$\begin{array}{llllllll}3.000 \mathrm{E}+00 & 1.85 \mathrm{E}-04 & 3.04 \mathrm{E}-02 & 1.20 \mathrm{E}-03 & 7.51 \mathrm{E}-03 & 1.06 \mathrm{E}-05 & 3.93 \mathrm{E}-02 & 3.91 \mathrm{E}-02\end{array}$

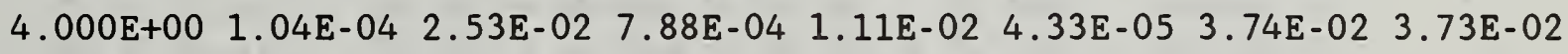

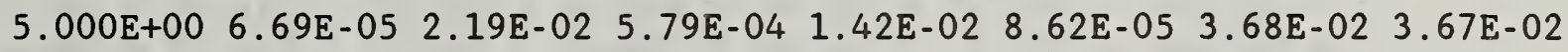

$\begin{array}{llllllll}6.000 \mathrm{E}+00 & 4.65 \mathrm{E}-05 & 1.93 \mathrm{E}-02 & 4.55 \mathrm{E}-04 & 1.68 \mathrm{E}-02 & 1.32 \mathrm{E}-04 & 3.68 \mathrm{E}-02 & 3.67 \mathrm{E}-02\end{array}$

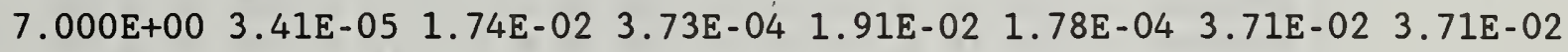

$\begin{array}{llllllll}8.000 \mathrm{E}+00 & 2.61 \mathrm{E}-05 & 1.58 \mathrm{E}-02 & 3.15 \mathrm{E}-04 & 2.12 \mathrm{E}-02 & 2.23 \mathrm{E}-04 & 3.76 \mathrm{E}-02 & 3.76 \mathrm{E}-02\end{array}$

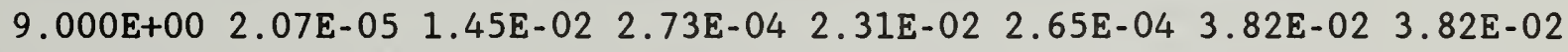

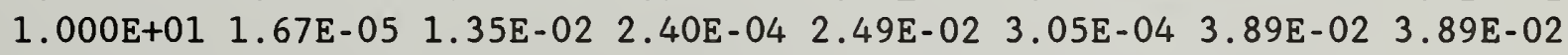

$\begin{array}{llllllll}1.100 \mathrm{E}+01 & 1.38 \mathrm{E}-05 & 1.26 \mathrm{E}-02 & 2.14 \mathrm{E}-04 & 2.65 \mathrm{E}-02 & 3.44 \mathrm{E}-04 & 3.96 \mathrm{E}-02 & 3.96 \mathrm{E}-02\end{array}$

$1.200 \mathrm{E}+01$ 1.16E-05 1.18E-02 1.93E-04 2.80E-02 3.80E-04 4.04E-02 4.03E-02

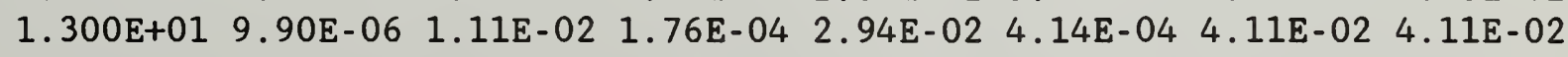

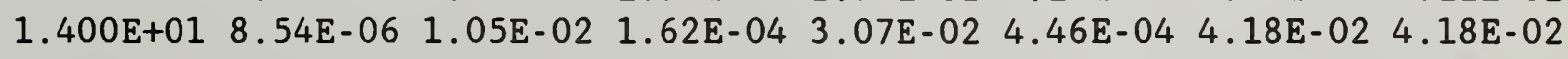

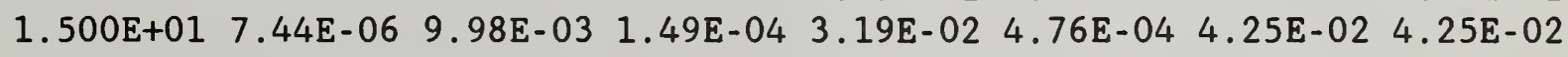

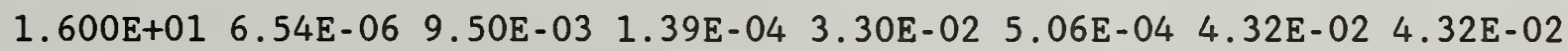

1. 800E+01 5.17E-06 8.68E-03 1.22E-04 3.51E-02 5.60E-04 4.44E-02 $4.44 \mathrm{E}-02$

$2.000 \mathrm{E}+01 \quad 4.18 \mathrm{E}-06 \quad 8.01 \mathrm{E}-03 \quad 1.08 \mathrm{E}-04 \quad 3.69 \mathrm{E}-02 \quad 6.09 \mathrm{E}-04 \quad 4.56 \mathrm{E}-02 \quad 4.56 \mathrm{E}-02$

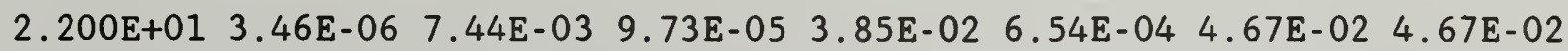

$2.400 \mathrm{E}+012.91 \mathrm{E}-06 \quad 6.95 \mathrm{E}-03 \quad 8.85 \mathrm{E}-05 \quad 4.00 \mathrm{E}-02 \quad 6.95 \mathrm{E}-04 \quad 4.78 \mathrm{E}-02 \quad 4.78 \mathrm{E}-02$

$2.600 \mathrm{E}+01$ 2.48E-06 6.53E-03 8.11E-05 4.14E-02 $7.33 \mathrm{E}-04 \quad 4.87 \mathrm{E}-02 \quad 4.87 \mathrm{E}-02$

$2.800 \mathrm{E}+012.13 \mathrm{E}-06 \quad 6.16 \mathrm{E}-03 \quad 7.48 \mathrm{E}-05 \quad 4.27 \mathrm{E}-02 \quad 7.69 \mathrm{E}-04 \quad 4.97 \mathrm{E}-02 \quad 4.97 \mathrm{E}-02$

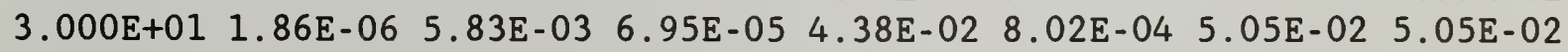

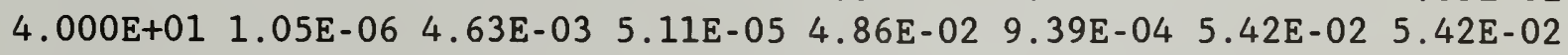

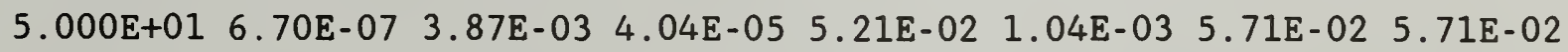




\section{Table 2 (Continued)}

Calcium Tungstate

Constituents (Atomic Number:Fraction by Weight)

$8: 0.22227 \quad 20: 0.13920 \quad 74: 0.63853$

Partial Interaction Coefficients and Total Attenuation Coefficients

PHOTON

SCATTERING

PHOTO-

PAIR PRODUCTION

ENERGY

COHERENT INCOHER. ELECTRIC

IN

IN

TOTAL ATTENUATION WITH WITHOUT

ABSORPTION NUCLEAR ELECTRON COHERENT COHERENT

$(\mathrm{MeV})$ $(\mathrm{cm} 2 / \mathrm{g}) \quad(\mathrm{cm} 2 / \mathrm{g}) \quad(\mathrm{cm} 2 / \mathrm{g})$ FIELD FIELD SCATT. SCATT. $(\mathrm{cm} 2 / \mathrm{g}) \quad(\mathrm{cm} 2 / \mathrm{g}) \quad(\mathrm{cm} 2 / \mathrm{g}) \quad(\mathrm{cm} 2 / \mathrm{g})$

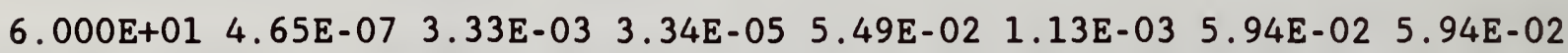
$\begin{array}{llllllll}8.000 \mathrm{E}+01 & 2.61 \mathrm{E}-07 & 2.63 \mathrm{E}-03 & 2.48 \mathrm{E}-05 & 5.89 \mathrm{E}-02 & 1.25 \mathrm{E}-03 & 6.28 \mathrm{E}-02 & 6.28 \mathrm{E}-02\end{array}$

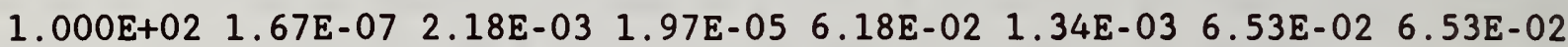

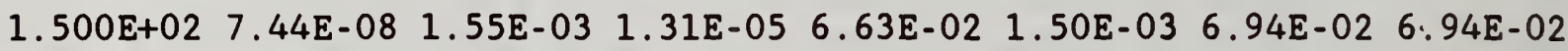
$2.000 \mathrm{E}+02 \quad 4.18 \mathrm{E}-08$ 1.22E-03 $9.76 \mathrm{E}-06 \quad 6.90 \mathrm{E}-02 \quad 1.60 \mathrm{E}-03 \quad 7.19 \mathrm{E}-02 \quad 7.19 \mathrm{E}-02$

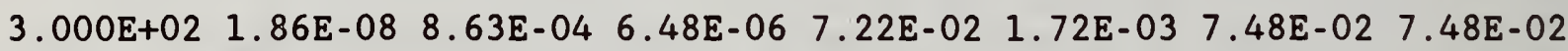
$4.000 \mathrm{E}+02 \quad 1.05 \mathrm{E}-08 \quad 6.76 \mathrm{E}-04 \quad 4.85 \mathrm{E}-06 \quad 7.40 \mathrm{E}-02 \quad 1.79 \mathrm{E}-03 \quad 7.65 \mathrm{E}-02 \quad 7.65 \mathrm{E}-02$ $5.000 \mathrm{E}+02 \quad 6.70 \mathrm{E}-09$ 5.60E-04 3.87E-06 7.52E-02 $1.84 \mathrm{E}-03 \quad 7.76 \mathrm{E}-02 \quad 7.76 \mathrm{E}-02$

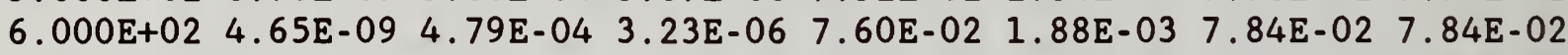
8.000E+02 2.61E-09 3.74E-04 2.42E-06 7.72E-02 1.93E-03 7.95E-02 7.95E-02 $1.000 \mathrm{E}+03$ 1.67E-09 3.08E-04 1.93E-06 7.79E-02 1.97E-03 8.02E-02 8.02E-02

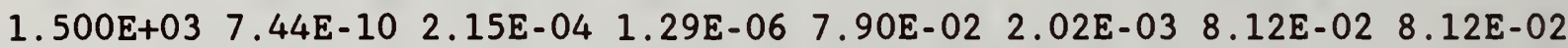
$2.000 \mathrm{E}+03 \quad 4.18 \mathrm{E}-10 \quad 1.66 \mathrm{E}-04 \quad 9.65 \mathrm{E}-07 \quad 7.95 \mathrm{E}-02 \quad 2.05 \mathrm{E}-03 \quad 8.18 \mathrm{E}-02 \quad 8.18 \mathrm{E}-02$

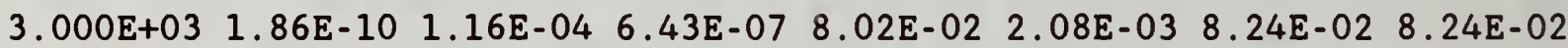
4.000E+03 1.05E-10 8.93E-05 4.82E-07 8.05E-02 2.10E-03 8.27E-02 8.27E-02

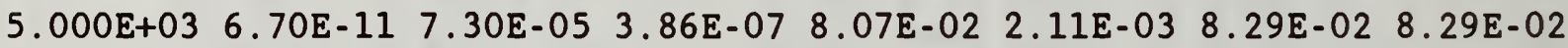
6.000E+03 4.65E-11 6.19E-05 3.21E-07 8.09E-02 2.12E-03 8.30E-02 8.30E-02 8.000E+03 2.61E-11 4.77E-05 2.41E-07 8.11E-02 2.13E-03 8.32E-02 8.32E-02

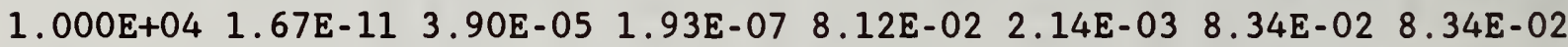

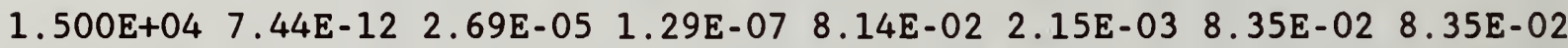

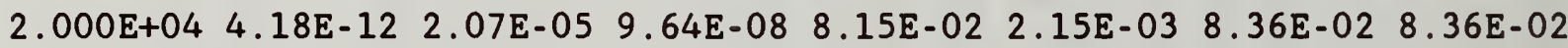
$\begin{array}{llllllll}3.000 \mathrm{E}+04 & 1.86 \mathrm{E}-12 & 1.43 \mathrm{E}-05 & 6.43 \mathrm{E}-08 & 8.15 \mathrm{E}-02 & 2.16 \mathrm{E}-03 & 8.37 \mathrm{E}-02 & 8.37 \mathrm{E}-02\end{array}$

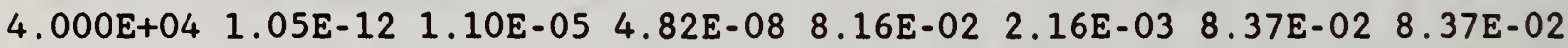
$\begin{array}{llllllll}5.000 \mathrm{E}+04 & 6.70 \mathrm{E}-13 & 8.92 \mathrm{E}-06 & 3.86 \mathrm{E}-08 & 8.16 \mathrm{E}-02 & 2.16 \mathrm{E}-03 & 8.38 \mathrm{E}-02 & 8.38 \mathrm{E}-02\end{array}$

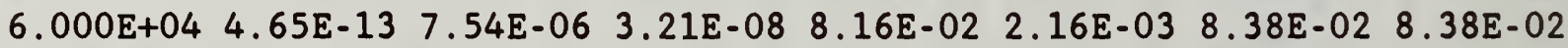

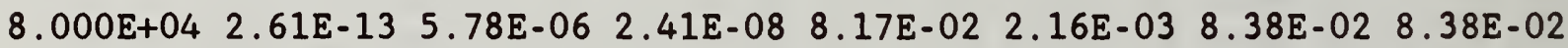

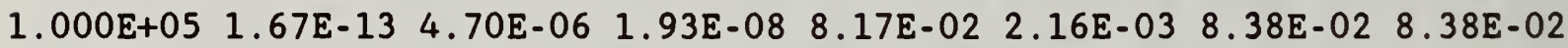




\section{Table 3}

Pyrex Glass

Constituents (Atomic Number:Fraction by Weight)

$\begin{array}{llllll}5: 0.04006 & 8: 0.53956 & 11: 0.02819 & 13: 0.01164 & 14: 0.37722 & 19: 0.00332\end{array}$

Partial Interaction Coefficients and Total Attenuation Coefficients

PHOTON SCATTERING PHOTO- PAIR PRODUCTION TOTAL ATTENUATION

ENERGY COHERENT INCOHER. ELECTRIC IN IN WITH WITHOUT ABSORPTION NUCLEAR ELECTRON COHERENT COHERENT FIELD FIELD SCATT. SCATT.

$\begin{array}{llllllll}(\mathrm{MeV}) & (\mathrm{cm} 2 / \mathrm{g}) & (\mathrm{cm} 2 / \mathrm{g}) & (\mathrm{cm} 2 / \mathrm{g}) & (\mathrm{cm} 2 / \mathrm{g}) & (\mathrm{cm} 2 / \mathrm{g}) & (\mathrm{cm} 2 / \mathrm{g}) & (\mathrm{cm} 2 / \mathrm{g})\end{array}$

8.040E-02 1.45E-02 $1.50 \mathrm{E}-01 \quad 2.40 \mathrm{E}-02 \quad 0.00 \mathrm{E}-01 \quad 0.00 \mathrm{E}-01 \quad 1.88 \mathrm{E}-01 \quad 1.74 \mathrm{E}-01$

2.790E-01 1.32E-03 1.08E-01 4.61E-04 0.00E-01 $0.00 \mathrm{E}-01 \quad 1.10 \mathrm{E}-01$ 1.09E-01

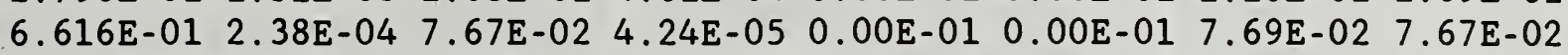

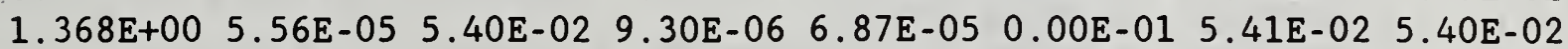

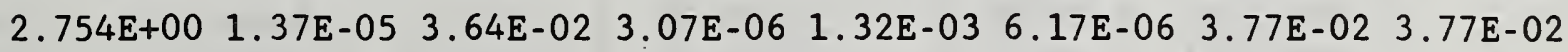


Calcium Tungstate

3

$8 \quad 20 \quad 74$

$\begin{array}{llll}0.222271 & 0.139196 & 0.638533\end{array}$

11

$\begin{array}{cr}3 & 3 \\ \text { ENERGY } & \text { LIST }\end{array}$

$1.0000 \mathrm{E}-03$

33

34

6

3

3

8

66

1.8092E-03

1.5000E-03 1.8092E-03

$1.8716 \mathrm{E}-03$

1. $8401 \mathrm{E}-03$

$1.8716 \mathrm{E}-03$

$2.2810 \mathrm{E}-03$

2.0000E-03

$2.2810 \mathrm{E}-03$

$2.5749 \mathrm{E}-03$

$2.4235 E-03$

$2.5749 \mathrm{E}-03$

$2.8196 \mathrm{E}-03$

$2.6945 \mathrm{E}-03$

$2.8196 \mathrm{E}-03$

4.0381E-03

$3.0000 \mathrm{E}-03$

4.0000E -03

$1.0207 \mathrm{E}-02$

5. $0000 \mathrm{E}-03$

$6.0000 \mathrm{E}-03$

1. 0855E-02

1. 1544E-02

1. 1544E-02

1. $1819 \mathrm{E}-02$

1. 2100E-02

1. 5000E-02

6.0000E-02

6.9525E-02

$6.9525 \mathrm{E}-02$

8.0000E-02

4. $0000 \mathrm{E}-01$

$5.0000 \mathrm{E}-01$

1. 2100E-02

2. 0000E-02

4.0381E-03

8.0000E-03

1.0000E-02 1.0207E-02

1. $2500 \mathrm{E}+00$

1. $5000 \mathrm{E}+00$

1. $0000 \mathrm{E}-01$

3. $0000 E-02$

4. 0000E-02

5. 0000E- 02

$5.0000 \mathrm{E}+00$

$6.0000 \mathrm{E}+00$

1. $1000 \mathrm{E}+01$

1. $2000 \mathrm{E}+01$

1. $8000 \mathrm{E}+01$

3. $0000 \mathrm{E}+01$

2. $0000 \mathrm{E}+01$

4. $0000 \mathrm{E}+01$

1. 5000E+02

$2.0000 \mathrm{E}+02$

8. $0000 E+02$

$1.0000 \mathrm{E}+03$

$5.0000 \mathrm{E}+03$

$6.0000 \mathrm{E}+03$

$6.0000 \mathrm{E}-01$

1. 5000E-01

2. $0000 E-01$

3. $0000 E-01$

2. $0000 \mathrm{E}+00$

$7.0000 \mathrm{E}+00$

8.0000E-01

$1.0000 \mathrm{E}+00$

1. $0220 \mathrm{E}+00$

$2.0440 E+00$

$3.0000 \mathrm{E}+00$

4. $0000 \mathrm{E}+00$

1. $3000 \mathrm{E}+01$

8. $0000 \mathrm{E}+00$

$9.0000 \mathrm{E}+00$

1. $0000 \mathrm{E}+01$

2. $2000 \mathrm{E}+01$

$1.4000 \mathrm{E}+01$

1. $5000 \mathrm{E}+01$

1. $6000 \mathrm{E}+01$

$5.0000 E+01$

$2.4000 \mathrm{E}+01$

2. $6000 \mathrm{E}+01$

2. $8000 E+01$

3. $0000 \mathrm{E}+02$

$6.0000 \mathrm{E}+01$

$8.0000 \mathrm{E}+01$

1. $0000 \mathrm{E}+02$

1. 5000E+03

4. $0000 \mathrm{E}+02$

$5.0000 \mathrm{E}+02$

$6.0000 \mathrm{E}+02$

$2.0000 E+03$

$3.0000 \mathrm{E}+03$

$4.0000 E+03$

$3.0000 \mathrm{E}+04$

4. $0000 \mathrm{E}+04$

8. $0000 E+03$

$1.0000 \mathrm{E}+04$

1. $5000 \mathrm{E}+04$

2. $0000 E+04$

$6.0000 \mathrm{E}+04$

8. $0000 E+04$

1. $0000 \mathrm{E}+05$

TOTAL ATTENUATION COEFFICIENT

4.0495E+03

1. $1899 \mathrm{E}+03$

$1.6322 \mathrm{E}+03$

$1.0575 E+03$

2. $3131 E+03$

$1.5735 \mathrm{E}+03$

2. $1483 E+03$

2. $2784 \mathrm{E}+03$

2. $7698 \mathrm{E}+03$

1. $9900 \mathrm{E}+03$

$1.9638 \mathrm{E}+03$

$1.6929 \mathrm{E}+03$

1. $7908 \mathrm{E}+03$

$1.6087 \mathrm{E}+03$

1. $5028 \mathrm{E}+03$

7.5927E+02

1. $6254 \mathrm{E}+02$

1. $3000 \mathrm{E}+03$

4. 4777E+02

1. $3812 \mathrm{E}+02$

1. $5720 \mathrm{E}+02$

1. $4848 \mathrm{E}+02$

1. $6045 \mathrm{E}+02$

2. $5046 \mathrm{E}+00$

9. $3237 E+01$

7. $2791 \mathrm{E}+00$

1. $5778 \mathrm{E}-01$

5.6217E-02

3. $6786 \mathrm{E}-02$

3. $9614 \mathrm{E}-02$

4. 4424E-02

5.0533E-02

6.9396E-02

7. $9486 \mathrm{E}-02$

8. 2911E-02

8. 3700E-02

1. $7354 \mathrm{E}+00$

$5.0744 \mathrm{E}+00$

1. 1972E-01

5.0699E-02

3. 6783E-02

4.0351E-02

4. 5603E-02

5. 4205E-02

7.1870E-02

8.0195E-02

$1.4450 \mathrm{E}+03$

$6.4832 E+02$

$2.8242 E+02$

1. 1740E+02

$6.3335 \mathrm{E}+02$

1. $3550 \mathrm{E}+02$

$7.6199 \mathrm{E}+01$

7. 2272E+01

$1.4025 \mathrm{E}+02$

4. 3974E+01

1. $5165 \mathrm{E}+01$

$7.1246 E+00$

$3.9886 E+00$

2. $9034 E+00$

$1.0632 \mathrm{E}+00$

5. $4755 \mathrm{E}-01$

$2.4607 \mathrm{E}-01$

$9.9070 \mathrm{E}-02$

$7.7172 \mathrm{E}-02$

6.5311E-02

$6.4292 \mathrm{E}-02$

$4.4515 \mathrm{E}-02$

$3.7104 \mathrm{E}-02$

$4.4146 \mathrm{E}-02$

$3.9276 \mathrm{E}-02$

$3.7398 \mathrm{E}-02$

$4.1069 \mathrm{E}-02$

$3.7611 \mathrm{E}-02$

$3.8230 \mathrm{E}-02$

$3.8907 \mathrm{E}-02$

$4.6722 \mathrm{E}-02$

$4.1799 \mathrm{E}-02$

4. 2480E-02

$4.3170 E-02$

$5.7067 \mathrm{E}-02$

$4.7776 \mathrm{E}-02$

4.8749E-02

$4.9680 \mathrm{E}-02$

$7.4778 \mathrm{E}-02$

$5.9353 \mathrm{E}-02$

6.2822E-02

$6.5323 \mathrm{E}-02$

8.1200E-02

$7.6484 \mathrm{E}-02$

$7.7604 \mathrm{E}-02$

$7.8402 \mathrm{E}-02$

8. $3036 \mathrm{E}-02$

$8.3232 \mathrm{E}-02$

8.2377E-02

8. $2695 \mathrm{E}-02$

$8.3525 \mathrm{E}-02$

8. $3623 \mathrm{E}-02$

$8.3749 \mathrm{E}-02$

8. 3795E-02

8. 3798E-02

8. 3845E-02

8.3847E-02 


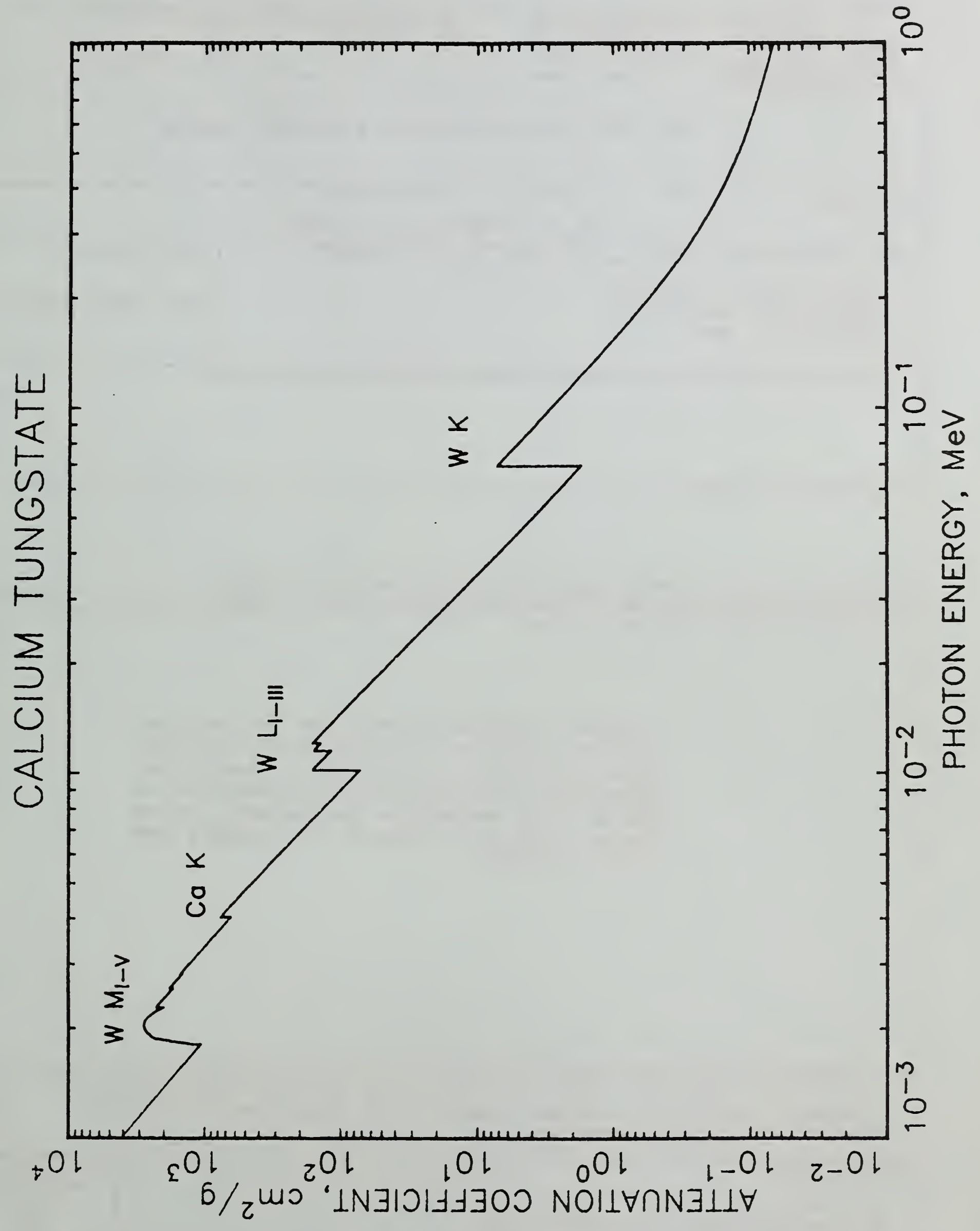

Fig. 1. Total Mass attenuation coefficient for calcium tungstate 
NBS.114A (REV. 2.80)

\begin{tabular}{|c|c|c|c|}
\hline $\begin{array}{c}\text { U.s. DEP T. OF COMM. } \\
\text { BIBLIOGRAPHIC DATA } \\
\text { SHEET (See instructions) }\end{array}$ & $\begin{array}{c}\text { 1. PUBLICATION OR } \\
\text { REPORT NO. } \\
\text { NBSIR 87-3597 }\end{array}$ & 2. Performing Organ. Report Nof 3. Publication Date & JULY 1987 \\
\hline 4. TITLE AND SUBTITLE & \& & & JU \\
\hline
\end{tabular}

\section{XCOM: Photon Cross Sections on a Personal Computer}

5. AUTHOR(S)

M. J. Berger and J. H. Hubbell

6. PERFORMING ORGANIZATION (If joint or other than NBS, see instructions)

7. Contract/Grant No.

NATIONAL BUREAU OF STANDARDS

DEPARTMENT OF COMMERCE

8. Type of Report \& Perlod Covered

WASHINGTON, D.C. 20234

9. SPONSORING ORGANIZATION NAME AND COMPLETE ADDRESS (Street, Clty, State, ZIP)

10. SUPPLEMENTARY NOTES

Document describes a computer program; SF-185, FIPS Software Summary, is attached.

11. ABSTRACT (A 200-word or less factual summary of most significant information. If document Includes a signlficant bibliography or literature survey. mention it here)

A computer program and data base are presented wi.ich can be used to calculate, with a personal computer, photon cross sections for scattering, photoelectric absorption and pair production, as well as total attenuation coefficients, in any element, compound or mixture, at energies from $1 \mathrm{keV}$ to $100 \mathrm{GeV}$.

12. KEY WORDS (Six to twelve entries: alphabetical order; capitalize only proper names; and separate key words by semicolons) attenuation coefficient; computer program; pair production; photoelectric absorption; photons; scattering

13. AVAILABILITY

[X] Unlimited

For Officlal Distribution. Do Not Release to NTIS

Order From Superintendent of Documents, U.S. Government Printing Office, Washington, D.C. 20402.

$[X]$ Order From National Technical Information Service (NTIS), Springfieid, VA. 2216I
14. NO. OF PRINTED PAGES

28

15. Price

$\$ 11.95$ 
